\title{
Tropospheric aerosol microphysics simulation with assimilated meteorology: model description and intermodel comparison
}

\author{
W. Trivitayanurak ${ }^{1}$, P. J. Adams ${ }^{1,2}$, D. V. Spracklen ${ }^{3, *}$, and K. S. Carslaw ${ }^{4}$ \\ ${ }^{1}$ Department of Civil and Environmental Engineering, Carnegie Mellon University, Pittsburgh, Pennsylvania, USA \\ ${ }^{2}$ Department of Engineering and Public Policy, Carnegie Mellon University, Pittsburgh, Pennsylvania, USA \\ ${ }^{3}$ School of Engineering and Applied Sciences, Harvard University, Cambridge, Massachusetts, USA \\ ${ }^{4}$ Institute of Atmospheric Science, School of Earth and Environment, University of Leeds, UK \\ *now at: Institute of Atmospheric Science, School of Earth and Environment, University of Leeds, UK
}

Received: 31 August 2007 - Published in Atmos. Chem. Phys. Discuss.: 10 October 2007

Revised: 13 February 2008 - Accepted: 26 May 2008 - Published: 24 June 2008

\begin{abstract}
We implement the TwO-Moment Aerosol Sectional (TOMAS) microphysics module into GEOS-CHEM, a CTM driven by assimilated meteorology. TOMAS has 30 size sections covering $0.01-10 \mu \mathrm{m}$ diameter with conservation equations for both aerosol mass and number. The implementation enables GEOS-CHEM to simulate aerosol microphysics, size distributions, mass and number concentrations. The model system is developed for sulfate and seasalt aerosols, a year-long simulation has been performed, and results are compared to observations. Additionally model intercomparison was carried out involving global models with sectional microphysics: GISS GCM-II' and GLOMAP. Comparison with marine boundary layer observations of $\mathrm{CN} 10$ and $\mathrm{CCN}(0.2 \%)$ shows that all models perform well with average errors of $30-50 \%$. However, all models underpredict $\mathrm{CN} 10$ by up to $42 \%$ between $15^{\circ} \mathrm{S}$ and $45^{\circ} \mathrm{S}$ while overpredicting CN10 up to $52 \%$ between $45^{\circ} \mathrm{N}$ and $60^{\circ} \mathrm{N}$, which could be due to the sea-salt emission parameterization and the assumed size distribution of primary sulfate emission, in each case respectively. Model intercomparison at the surface shows that GISS GCM-II' and GLOMAP, each compared against GEOS-CHEM, both predict $40 \%$ higher CN10 and predict $20 \%$ and $30 \%$ higher $\mathrm{CCN}(0.2 \%)$ on average, respectively. Major discrepancies are due to different emission inventories and transport. Budget comparison shows GEOSCHEM predicts the lowest global $\mathrm{CCN}(0.2 \%)$ due to microphysical growth being a factor of 2 lower than other mod-
\end{abstract}

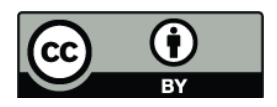

Correspondence to: W. Trivitayanurak (win@cmu.edu) els because of lower $\mathrm{SO}_{2}$ availability. These findings stress the need for accurate meteorological inputs, updated emission inventories, and realistic clouds and oxidant fields when evaluating global aerosol microphysics models.

\section{Introduction}

Atmospheric aerosols impact climate in two ways: directly reflecting solar radiation, known as the aerosol direct effect (Charlson et al., 1992), and acting as cloud condensation and ice nuclei (CCN and IN, respectively), thereby changing the reflectivity and the likelihood of precipitation, which is called the aerosol indirect effect(Albrecht, 1989; Twomey, 1974, 1977). The aerosol direct effect has been estimated with more certainty than the indirect effect. According to the Fourth Assessment Report of the Intergovernmental Panel on Climate Change (IPCC), the global and annual average indirect aerosol radiative forcing uncertainty range is between 1.8 and $-0.3 \mathrm{~W} \mathrm{~m}^{-2}$ (IPCC, 2007). Note that this uncertainty range refers to only the cloud brightness effect (first aerosol indirect effect), not including changes in cloud lifetime and distribution (second aerosol indirect effect); this underlines the need to improve the estimate of aerosol indirect radiative forcing.

The aerosol indirect effect is caused by $\mathrm{CCN}$, the subset of airborne particles that become cloud droplets. To reduce uncertainty in estimates of indirect radiative forcing, the links between emissions, $\mathrm{CCN}$, and cloud droplet number concentrations (CDNC) must be well simulated in models. Early attempts to predict CDNC used empirical

Published by Copernicus Publications on behalf of the European Geosciences Union. 
relationships between sulfate mass and CDNC without explicitly simulating aerosol and cloud microphysics (Boucher and Lohmann, 1995; Jones et al., 1994; Martin et al., 1994). This kind of empirical relationship is of limited use for locations and times other than where the relationship was measured. As pointed out by Kiehl (2000), limitations and uncertainties associated with the empirical approach suggest the need to take a mechanistic approach, for example by explicitly simulating aerosol number concentrations and size distributions. More recent aerosol models use a mechanistic approach to predicting $\mathrm{CCN}$ concentrations by including sizeresolved aerosol microphysics(Adams and Seinfeld, 2002; Easter et al., 2004; Ghan et al., 2001; Herzog et al., 2004; Spracklen et al., 2005b; Stier et al., 2005a; von Salzen et al., 2000; Wilson et al., 2001). The main difference in these models lies in how the aerosol size distributions are represented, e.g. the modal approach, single-moment sectional, and two-moment sectional methods. Two-moment sectional algorithms are advantageous in terms of conserving number and mass unlike the single-moment sectional algorithms that tend to have problems with numerical diffusion and/or conserving number concentrations (Tzivion et al., 1987) during the condensation process. Thus a two-moment sectional algorithm is applied in this study.

Apart from the numerical properties of the microphysics algorithm, the quality of aerosol predictions is directly dependent on accuracies of emissions inventories and other assumptions used in an aerosol model. The importance of nucleation treatment and assumptions regarding characteristics of primary aerosol emissions, e.g. their size distributions, have been the subjects of several studies (Adams and Seinfeld, 2002, 2003; Pierce and Adams, 2007; Spracklen et al., 2005a; Spracklen et al., 2006; Stier et al., 2005b). Although global models with mechanistic $\mathrm{CCN}$ predictions have been developed, substantial evaluation is needed to improve the quality of their predictions.

To test the aerosol microphysics model, aerosol predictions can be compared with atmospheric aerosol observations, especially aerosol number concentrations and size distributions. Ideally we want to have global, long-term, and highly time-resolved measurements of the full suite of aerosol chemical and physical properties, e.g. composition, hygroscopicity, size, shape, amount, mixing state. In reality, different measurement platforms and techniques provide limited observations covering different durations and locations. An intensive field campaign integrates multi-platform measurements by collocating instrumentation for reasonably detailed snapshots of the atmospheric aerosol. The primary limitations of a field campaign are cost and complexity, and resulting limited duration and coverage. Several field campaigns were carried out in parts of the globe during the last decade (Bates et al., 1998; Bates et al., 2001; Huebert et al., 2003; Jacob et al., 2003; Raes et al., 2000a; Ramanathan et al., 2001). The durations of these campaigns, which are on a scale of weeks, emphasize the need to accurately simulate global aerosol microphysics and accompanying meteorology at high time-resolution for aerosol model evaluation.

The aerosol microphysics model of interest in our work is the Two-Moment Aerosol Sectional (TOMAS) model, which was developed for sulfate aerosol in GISS GCM-II' model by Adams and Seinfeld (2002), hereafter referred to as AS02, with additional sea-salt implementation (Pierce and Adams, 2006). A GCM is advantageous because it generates its own meteorology and allows interaction of clouds with aerosol; thus, it can simulate the aerosol indirect effects. However, its inability to predict actual historical meteorological variation on a day-to-day timescale hinders model testing at high time-resolution against short-term field campaign observations. For this reason, the aerosol microphysics module needs to be implemented in a different host model driven by meteorology that matches the actual conditions during the field campaign period, which will allow detailed comparison against field campaign observations. A chemistrytransport model (CTM) driven by assimilated meteorology serves this purpose. In the long run, having a CTM-based aerosol microphysics model driven by assimilated meteorology will be beneficial for long-term comparisons as well, such as with global aerosol satellite observations. Evaluating against a long-term data set, the ability to have accurate synoptic variability in meteorological fields allows a more demanding high time resolution comparison.

Model intercomparison is another exercise to assess global aerosol models relative to each other. Although model intercomparison does not provide a definitive test of performance it can reveal behaviors, diversities, and sensitivities of different process treatments among models and suggest observations required to eliminate intermodel discrepancies. An exhaustive model intercomparison activity would involve numerous models and tightly constrained scenarios designed to isolate the effects of different processes and inputs. A more limited model intercomparison compares models as they are and looks at the intermodel discrepancies to indicate the range of uncertainty currently facing the scientific community. This work presents this more limited style of intercomparison. Intercomparison of aerosol budgets offers deeper insight to the contributions of controlling processes even if the predicted global concentrations are similar. Several model intercomparisons performed in the past provided snapshots of the collective performance of global aerosol models, though the focus was on aerosol mass (Barrie et al., 2001; IPCC, 2001; Textor et al., 2006). Model intercomparison of aerosol number and aerosol size distributions are lacking but are more relevant for evaluating $\mathrm{CCN}$ predictions in global aerosol microphysics models, and is a goal of this work.

This paper documents the implementation of the TOMAS microphysics module into the GEOS-CHEM host model, which is driven by assimilated meteorology. Simulation results for sulfate and sea-salt aerosols are presented. Additionally, the results from GEOS-CHEM are compared with 
two other global aerosol microphysics models with twomoment sectional algorithms. Future work will incorporate carbonaceous and mineral dust aerosols and present comparisons against field campaign data.

Section 2 describes the GEOS-CHEM host model, the TOMAS microphysics module and its implementation, and also briefly describes other models included in our intercomparison. Section 3 presents model results from GEOSCHEM. Section 4 shows comparison of model predictions with field observations. Section 5 discusses model intercomparison. Finally, Sect. 6 briefly concludes this work.

\section{Model descriptions}

In this section, we describe the host model, GEOS-CHEM, and the TOMAS aerosol microphysics module. Next we discuss the models for intercomparison, GISS GCM-II' and GLOMAP. The scope of this work is limited to sulfate and sea-salt aerosol simulations. In some regions, these two aerosol species are dominant and model predictions should be realistic while some regions the lack of other aerosols, e.g. carbonaceous aerosols, dust, can be significant.

\subsection{GEOS-CHEM and TOMAS}

GEOS-CHEM is a global three-dimensional model of tropospheric chemistry driven by assimilated meteorological observations from the Goddard Earth Observing System (GEOS) of the NASA Global Modeling and Assimilation Office (GMAO) (Bey et al., 2001). We chose to use GEOS-CHEM with a horizontal grid resolution of $4^{\circ}$ latitude by $5^{\circ}$ longitude and a 30 -level sigma-coordinate vertical grid between the surface and $0.01 \mathrm{hPa}$ at the model top of atmosphere. Prior to this work, the GEOS-CHEM model tracked only aerosol mass and had no aerosol microphysical simulation. Bulk aerosol mass of sulfate (Park et al., 2004) and carbonaceous aerosols were predicted. Sea-salt mass was tracked in 2 bins and dust mass was tracked in 4 bins (Alexander et al., 2005; Fairlie et al., 2004).

The main changes to the original GEOS-CHEM are replacement of the original aerosol treatments with the TOMAS module for sulfate and sea-salt. Tracers are added to GEOS-CHEM with 30 tracers to represent the size distributions of each of the following: aerosol number, sulfate mass, and sea-salt mass. We use the GEOS-CHEM model version 5.07.08 (http://www-as.harvard.edu/chemistry/trop/ geos/index.html). The size-resolved sulfate aerosol introduced to the GEOS-CHEM model as described in this work is based on AS02. The implementation of sizeresolved sea-salt aerosol is based on the work by Pierce and Adams (2006). The 2001 simulation was initialized on 1 November 2000 and conducted for 14 months, in which the first 2 months was used only for model initialization. In this work, microphysical processes in GEOS-CHEM are limited to the troposphere for computational expediency.

\subsubsection{TOMAS microphysics model}

The TwO-Moment Aerosol Sectional (TOMAS) microphysics model is incorporated into the host model, GEOSCHEM, to account for aerosol microphysical processes. Details of the development of TOMAS are described in AS02. Here we summarize key information about TOMAS and highlight differences between its implementation in GEOSCHEM compared to GISS GCM-II' in AS02.

A key feature of TOMAS is its ability to track two independent moments of the aerosol size distribution for each size bin. The two moments that we track are aerosol number concentration and mass concentration. There are 30 size sections segregated by dry aerosol mass, and the upper boundary of each size section is twice the mass of the lower boundary. The smallest particle that we track is $10^{-21} \mathrm{~kg}$ dry aerosol mass per particle, which is about $0.01 \mu \mathrm{m}$ dry diameter for a typical aerosol density of $1.8 \mathrm{~g} \mathrm{~cm}^{-3}$. For the upper boundary of the largest size section, the particle size is close to $10 \mu \mathrm{m}$ dry diameter. We assume all aerosols to be internally mixed. Even though assuming sea-salt and sulfate to be internally mixed instantaneously is physically unrealistic, the assumption works for our purpose of focusing on $\mathrm{CCN}$ since both sea-salt and sulfate activate at similar diameters $(\sim 80 \mathrm{~nm}$ for $0.2 \%$ supersaturation). For aerosol physical properties, we assume all sulfate exists uniformly as ammonium bisulfate. With the water uptake curve of ammonium bisulfate and sodium chloride calculated offline, the density of the ammonium bisulfate-sea-salt-water mixture can be calculated at any time.

Microphysical processes include coagulation, condensation/evaporation, nucleation, and in-cloud sulfur oxidation. Coagulation, an important sink of aerosol number and a means for freshly nucleated particles to grow to larger sizes, is based on the method developed by Tzivion et al. (1987) with an assumption that particles coagulate via Brownian diffusion neglecting gravitational settling and turbulence effects (Adams and Seinfeld, 2002). Condensation of gas-phase sulfuric acid to existing particles, an important source of aerosol mass by which small particles grow to become $\mathrm{CCN}$, is modeled using the algorithm by Tzivion et al. (1989).

Nucleation accounts for a very small and insignificant addition of mass by gas-to-particle conversion but contributes significantly to the aerosol number concentrations and size distributions. The nucleation treatment is based on binary nucleation (Jaecker-Voirol and Mirabel, 1989). Their nucleation rate calculation is simplified into a calculation of a critical $\mathrm{H}_{2} \mathrm{SO}_{4}$ concentration for significant nucleation with the critical concentration being a function of temperature and relative humidity (Wexler et al., 1994). This critical sulfuric acid concentration is the criteria for determining when nucleation occurs in the model. As in AS02, we treat nucleation 
in a simple way by first allowing gas-phase sulfuric acid to condense onto existing particles during one model time step $(1 \mathrm{~h})$. At the end of the time step, if the remaining gas-phase sulfuric acid concentration exceeds the critical concentration, then the remaining mass nucleates. Although there are uncertainties surrounding the actual nucleation mechanism in the atmosphere, binary nucleation with this simple treatment appears to perform relatively well in AS02 as they predict reasonable $\mathrm{CN}$ number concentrations in the upper troposphere.

In-cloud oxidation modifies the aerosol size distribution as the particles activate into cloud droplets, gain sulfate mass by aqueous chemistry, then water evaporates resulting in larger particles than prior to entering the cloud. In this work, the amount of sulfate produced by in-cloud chemistry is calculated based on the treatment in the original GEOS-CHEM model as described in Park et al. (2004) and includes reactions with both hydrogen peroxide and ozone. Sulfate produced by aqueous oxidation is distributed over size bins large enough to activate as described in AS02.

Regarding assumed activation diameter, there is a distinct difference in this work compared to ASO2. In ASO2, the GISS GCM II' handles in-cloud oxidation in two separate cloud types: stratiform and convective clouds. GEOSCHEM, in contrast, does not distinguish between aqueous chemistry in stratiform and convective clouds. AS02 assumed that the GCM's stratiform clouds experienced a maximum of $0.19 \%$ supersaturation corresponding to the activation diameter of $0.082 \mu \mathrm{m}$. Similarly, for convective clouds the maximum supersaturation was $0.75 \%$, and the activation diameter was $0.033 \mu \mathrm{m}$. For this work and for purposes of in-cloud oxidation, the activation diameter is assumed to be $0.055 \mu \mathrm{m}$, an average of those in AS02.

\subsection{Emissions}

Sulfur emissions in GEOS-CHEM are based on the Global Emissions Inventory Activity (GEIA) for 1985 with updated national emission inventories and fuel use data (Bey et al., 2001; Park et al., 2004). Anthropogenic sulfur is emitted as $\mathrm{SO}_{2}$ and a small fraction as sulfate (5\% in Europe and 3\% elsewhere) (Chin et al., 2000). The original sulfur simulation in GEOS-CHEM emitted sulfate as bulk sulfate mass. Here we introduce size-resolved sulfate emission by distributing the emitted sulfate across different size sections using a bimodal and lognormal size distribution with number geometric mean diameters of 10 and $70 \mathrm{~nm}$ and standard deviations of 1.6 and 2.0, respectively (Adams and Seinfeld, 2002). The sulfate aerosol number emitted is calculated based on the bincenter mass per particle of each size section.

Regarding sea-salt emission, previous work (Alexander et al., 2005) incorporated sea-salt into GEOS-CHEM using the emission parameterization of Monahan et al. (1986). They introduced two modes of sea-salt aerosols, fine $(0.2-2 \mu \mathrm{m}$ dry diameter) and coarse $(2-20 \mu \mathrm{m})$ modes, aiming to study sulfate formation on sea-salt particles. In this work, we choose the sea-salt emission of Clarke et al. (2006) because it covers a wider size range of ultrafine emissions with important implications for marine $\mathrm{CN}$ and $\mathrm{CCN}$ concentrations (Pierce and Adams, 2006). The emission parameterization of Clarke et al. (2006) is derived from coastal field campaign data. This sea-salt emission is computed as a function of wind speed at $10 \mathrm{~m}$ above the ocean surface and covers the dry diameter range of $10 \mathrm{~nm}$ to $8 \mu \mathrm{m}$.

\subsection{Advection}

Tracer advection is calculated every $30 \mathrm{~min}$ using the TPCORE algorithm (Lin and Rood, 1996), a flux-form semiLagrangian transport scheme. TPCORE is a flexible algorithm that allows several choices of 1-D advection scheme to be applied for different directions as well as for different regions of the globe, e.g. to handle converging grids at the poles.

Despite the good performance of TPCORE in transporting individual tracers, TPCORE creates an inconsistency problem when it attempts to transport two related tracers. In this work, the aerosol mass and number in each size section are related quantities that must be advected together in a consistent fashion. The problem happens when the selected 1-D transport scheme, such as the Piecewise Parabolic Method (PPM)(Carpenter et al., 1990; Colella and Woodward, 1984), uses non-linear spatial interpolation. When the spatial distribution parabolas for the number and mass tracers are constructed separately, sub-grid regions with aerosols that are too large or too small (dry mass per particle above or below the size boundary) are artificially created due to the numeric of the interpolation. Our solution is to allow TPCORE to transport only the aerosol number tracers in each size section; we subsequently compute the corresponding mass advection based on the assumption that aerosols in each size bin and grid cell have a uniform size equal to the average dry mass per particle at that time and grid cell.

\subsection{Chemistry}

GEOS-CHEM includes the capability to simulate tropospheric photochemistry and sulfur chemistry. In a "full chemistry" run, concentrations of oxidants, i.e. $\mathrm{OH}, \mathrm{H}_{2} \mathrm{O}_{2}$, $\mathrm{O}_{3}$, are predicted based on a comprehensive set of photochemical reactions (Bey et al., 2001). Optionally, photochemistry can be turned off and archived monthly average oxidant fields used for the sulfur chemistry calculation. We did a full chemistry run for this study. The sulfur species include DMS, $\mathrm{SO}_{2}, \mathrm{H}_{2} \mathrm{SO}_{4}$, and MSA. Previously, the $\mathrm{H}_{2} \mathrm{SO}_{4}$ produced from $\mathrm{SO}_{2}$ oxidation was immediately converted into bulk sulfate mass. In this work, to represent the microphysical processes by which $\mathrm{H}_{2} \mathrm{SO}_{4}$ becomes sulfate, we add a new tracer for $\mathrm{H}_{2} \mathrm{SO}_{4}$ (gas), which then undergoes condensation and nucleation. Distinguishing the pathways by 


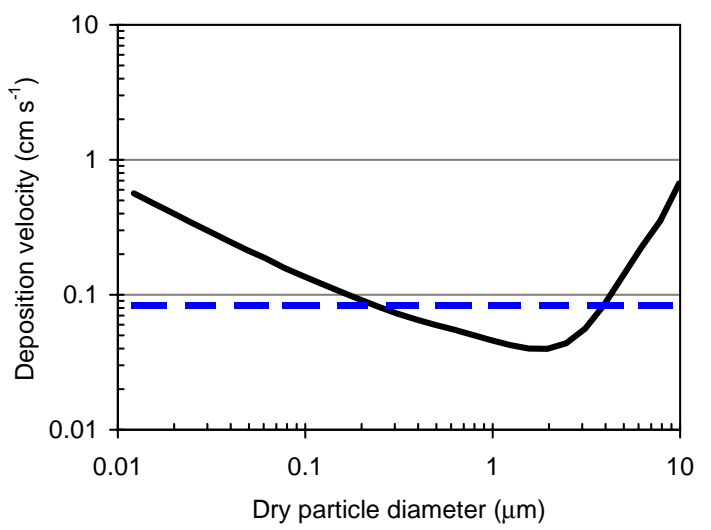

Fig. 1. Global and annual-average dry deposition velocities $\left(\mathrm{cm} \mathrm{s}^{-1}\right)$ as a function of particle size (solid curve). For comparison, the global and annual-average dry deposition velocity used for bulk sulfate in the original GEOS-CHEM is also plotted (straight, dashed line).

which gas-phase $\mathrm{H}_{2} \mathrm{SO}_{4}$ converts to aerosol sulfate is crucial for predicting aerosol number size distributions.

The existing sulfate-producing in-cloud chemistry in GEOS-CHEM is ready for coupling with TOMAS microphysics. The sulfate-producing aqueous chemistry in sea-salt particles as discussed in Alexander et al. (2005) is not included in this work because Alexander et al. (2005) found a small effect of including the mentioned aqueous oxidation pathway on the global lifetime and burden of sulfate.

\subsection{Dry deposition}

Dry deposition is modeled using the resistance-in-series approach. For sulfate and sea-salt aerosols, we implement size-resolved dry deposition velocities following the sizedependent scheme of Zhang et al. (2001). For all other species, dry deposition velocities are modeled using the approach of Wesely (1989) as described by Wang et al. (1998). Figure 1 shows annual and global area-weighted average dry deposition velocities as a function of aerosol diameter. For comparison, the original bulk aerosol dry deposition velocity is shown as the straight line.

\subsection{Wet deposition}

Wet deposition in GEOS-CHEM includes three main processes:

1. in-cloud scavenging (rainout),

2. below-cloud scavenging (washout),

3. and scavenging

in convective updrafts. In-cloud and below-cloud scavenging are treated separately for stratiform precipitation and convective anvils. Scavenging in convective updrafts represents
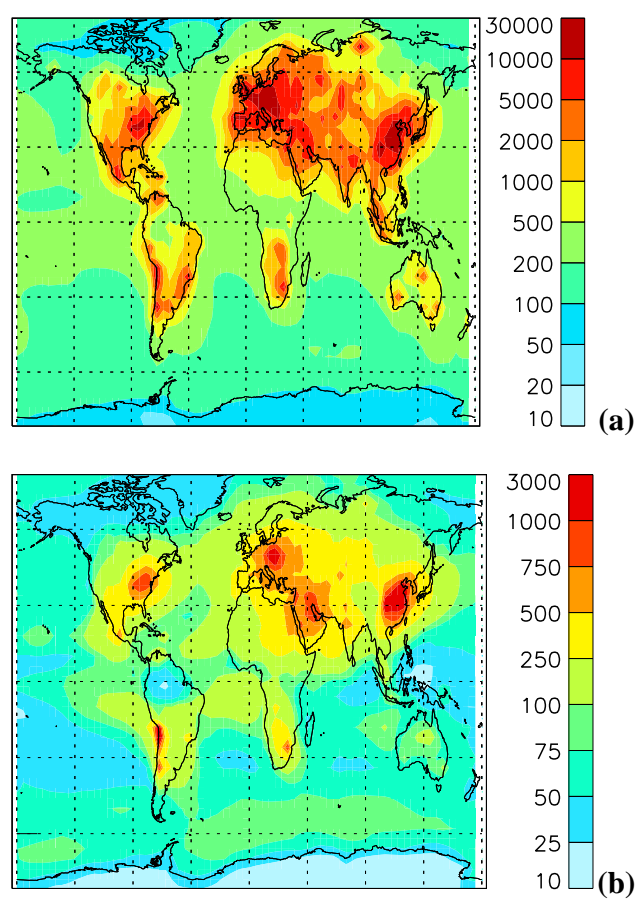

Fig. 2. GEOS-CHEM predicted annual average number concentrations $\left(\mathrm{cm}^{-3}\right.$ at STP conditions of $273 \mathrm{~K}$ and $\left.1 \mathrm{~atm}\right)$ in the lowest model layer for (a) $\mathrm{CN} 10$ and (b) $\mathrm{CCN}(0.2 \%)$.

removal in the convective column during vertical transport. Details of the wet deposition scheme used in GEOS-CHEM are described in Liu et al. (2001). Here we discuss the changes made to accommodate size-resolved wet deposition.

In-cloud scavenging, sometimes called "nucleation scavenging", is treated as a first-order loss utilizing the rainout rate constant computed by Giorgi and Chaimedes (1986). The rate constants are different for stratiform and convective anvil precipitation. We did not modify the original calculation of the rate constant but simply apply the assumption, similar to AS02, that only those particles larger than the activation diameter are subjected to removal. The activation diameter for large-scale precipitation is $0.082 \mu \mathrm{m}$ and for convective precipitation is $0.033 \mu \mathrm{m}$. These activation diameters were chosen based on the maximum supersaturations that stratiform and convective clouds typically experience of $0.19 \%$ and $0.75 \%$, respectively.

Below-cloud scavenging of gaseous and bulk aerosol species in the original GEOS-CHEM was calculated using a washout rate constant of $0.1 \mathrm{~mm}^{-1}$ of precipitation applied to the precipitating fraction of the grid area (Liu et al., 2001). Here we introduce size-resolved washout in the same way as in AS02. The size-dependent washout rate constants were taken from Fig. 2 of Dana and Hales (1976), which are theoretical washout rate coefficients as a function of aerosol size. 
The wet deposition scheme also allows release of scavenged aerosol during evaporation of precipitation below cloud. The assumption is, for a given fraction $f$ of evaporating precipitation, only $0.5 f$ of the scavenged aerosol load is released at that level. The 0.5 fraction is to account for a combination of drops that evaporate completely, releasing their entire dissolved aerosol, and drops that partly evaporate and do not release any dissolved aerosol (Koch et al., 1999). In the original GEOS-CHEM, the re-evaporating scavenged $\mathrm{SO}_{2}$ is put into the bulk $\mathrm{SO}_{4}$ aerosol assuming it has undergone aqueous oxidation. In this work, we distribute the reevaporating $\mathrm{SO}_{2}$ over the aerosol size distribution in the same way as $\mathrm{SO}_{4}$ produced by standard aqueous oxidation.

Scavenging in convective updrafts is calculated by a firstorder rate loss where the scavenged fraction is a function of scavenging efficiency and the height of the updraft column. Here we do not make any change to the scavenging fraction calculation. However, we apply the same assumption described above, namely that only activated particles are scavenged. For convective precipitation, these are particles larger than $0.033 \mu \mathrm{m}$.

\subsection{Models for intercomparison}

\subsection{GISS GCM-II' model}

The GISS GCM-II' model is a 3-D general circulation model. The TOMAS microphysics has been incorporated into the GISS GCM-II' and applied to sulfate aerosol as described in AS02. This work uses the model results from a later version of the GISS GCM-II' with the addition of sea-salt aerosol (Pierce and Adams, 2006). This version of GISS GCM-II' has a horizontal resolution of $4^{\circ}$ latitude by $5^{\circ}$ longitude and 9 sigma-coordinate levels from surface to $10 \mathrm{mb}$ level. GISS sulfur emission in the model is taken from the GEIA 1985 inventory. Specifically, we compare against the "CLRK" simulation of Pierce and Adams (2006), which calculated sea-salt emissions using same Clarke et al. (2006) parameterization adopted here.

Both the GEOS-CHEM model and the GISS GCM-II' model have similar implementations of TOMAS microphysics, so a major difference is simply their respective meteorological fields. Additionally, the GISS GCM II' uses prognostic $\mathrm{H}_{2} \mathrm{O}_{2}$ calculated from archived average photolysis rates and uses archived average oxidant fields for $\mathrm{OH}$, $\mathrm{HO}_{2}$, and $\mathrm{NO}_{3}$ (Koch et al., 1999 and references therein) while GEOS-CHEM, in this work, uses the option to calculate and update the oxidant fields simultaneously with photochemistry. Another important difference is the treatment of clouds for in-cloud oxidation; GISS GCM-II' explicitly handles stratiform and convective clouds separately while GEOS-CHEM does not. This leads to different treatments of aerosol activation during aqueous oxidation as described in Sect. 2.1.1.

\subsection{GLOMAP model}

GLOMAP (GLObal Model of Aerosol Processes) is a sizeresolved microphysics model which is an extension to the 3D offline Eulerian chemical transport model, TOMCAT, described in e.g. Stockwell and Chipperfield (1999). GLOMAP runs on assimilated meteorology from the European Centre for Medium-Range Weather Forecasts (ECMWF). The spatial resolution of the model grid is $2.8^{\circ}$ latitude by $2.8^{\circ}$ longitude with 31 hybrid sigma-pressure $(\sigma-p)$ levels extending from the surface to $10 \mathrm{mb}$ level. The aerosol size distributions are simulated using the moving-center scheme of Jacobson (1997b) and represented by 20 size sections having bin centers spanning 0.003 to $25 \mu \mathrm{m}$ equivalent dry diameters. The details of GLOMAP are described in Spracklen et al. (2005b). The results used in our comparison are from a version of GLOMAP that includes only sulfate and seasalt aerosols using the GEIA 1985 sulfur emission and the sea spray emission parameterization of Gong (2003). In this version of GLOMAP, oxidant $\left(\mathrm{OH}, \mathrm{H}_{2} \mathrm{O}_{2}, \mathrm{HO}_{2}\right.$, and $\left.\mathrm{NO}_{3}\right)$ concentrations are specified using 6-hourly monthly mean fields archived from TOMCAT detailed tropospheric chemistry simulations. We use GLOMAP model results from a simulation of year 1996 for our intercomparison.

Although GLOMAP and GEOS-CHEM with the TOMAS microphysics are models developed independently, there are several similarities. Both use assimilated meteorology. While both TOMAS and the moving-center algorithms are two-moment sectional approaches, they differ in the closure assumptions used to solve the aerosol general dynamic equation. TOMAS treats the aerosol size distribution within a section with either a "top hat" or "linear" approximation (Stevens, 1996; Tzivion et al., 1987, 1989) but the movingcenter approach treats the size distribution as monodisperse within the bin (Jacobson et al., 1994; Jacobson, 1997a). Both the two-moment sectional treatment of TOMAS and the moving center treatment in GLOMAP are high-resolution sectional treatments of the aerosol size distribution that have been evaluated against analytical solutions and found to be very accurate and guarantee that both number and mass balance equations are satisfied (Jacobson et al., 1994; Jacobson, 1997a; Tzivion et al., 1987). Any difference in aerosol prediction caused by these different microphysics schemes should be insignificant compared to the uncertainties of other model components, e.g. chemistry, deposition.

An important difference in GLOMAP microphysics and TOMAS microphysics are their nucleation parameterizations and how they treat the competition between nucleation and condensation. Both assume binary nucleation in the $\mathrm{H}_{2} \mathrm{SO}_{4}$ $\mathrm{H}_{2} \mathrm{O}$ system. While TOMAS uses a critical concentration of $\mathrm{H}_{2} \mathrm{SO}_{4}$ as a criterion for nucleation, GLOMAP explicitly calculates nucleation rates with the parameterization of Kulmala et al. (1998). Regarding the competition of nucleation and condensation for the available gas phase $\mathrm{H}_{2} \mathrm{SO}_{4}$, GLOMAP captures this competition by selecting a short 
Table 1. A summary comparison of the three aerosol models used in this work.

\begin{tabular}{|c|c|c|c|}
\hline & GEOS-CHEM & GISS GCM-II' & GLOMAP \\
\hline Aerosol microphysics model & TOMAS & TOMAS & GLOMAP \\
\hline Aerosol species & Sulfate Sea salt & Sulfate Sea salt & Sulfate Sea salt \\
\hline Aerosol size sections & 30 & 30 & 20 \\
\hline Equivalent size range $(\mu \mathrm{m})$ & $0.01-10$ (bin boundaries) & $0.01-10$ (bin boundaries) & $0.003-25$ (bin center) \\
\hline Aerosol microphysics algorithm & $\begin{array}{l}\text { Two-moment sectional } \\
\text { (Adams and Seinfeld, 2002) }\end{array}$ & $\begin{array}{l}\text { Two-moment sectional } \\
\text { (Adams and Seinfeld, 2002) }\end{array}$ & "Moving-center" (Jacobson, 1997) \\
\hline Nucleation & $\begin{array}{l}\text { Binary } \mathrm{H}_{2} \mathrm{SO}_{4}-\mathrm{H}_{2} \mathrm{O} \\
\text { "critical concentration" } \\
\text { (Jaecker-Voirol and Mirabel, 1989) }\end{array}$ & $\begin{array}{l}\text { Binary } \mathrm{H}_{2} \mathrm{SO}_{4}-\mathrm{H}_{2} \mathrm{O} \\
\text { "critical concentration" } \\
\text { (Jaecker-Voirol and Mirabel, 1989) }\end{array}$ & $\begin{array}{l}\text { Binary } \mathrm{H}_{2} \mathrm{SO}_{4}-\mathrm{H}_{2} \mathrm{O} \\
\text { rate calculation } \\
\text { (Kulmala et al., 1998) }\end{array}$ \\
\hline Host model type & CTM & GCM & CTM \\
\hline Meteorology & NASA GMAO & GISS GCM generated & ECMWF \\
\hline $\begin{array}{l}\text { Grid resolution } \\
\text { Horizontal/ vertical }\end{array}$ & $4^{\circ} \times 5^{\circ} / 30$ levels & $4^{\circ} \times 5^{\circ} / 9$ levels & $2.8^{\circ} \times 2.8^{\circ} / 31$ levels \\
\hline Sulfur emission & Updated GEIA & GEIA 1985 & GEIA 1985 \\
\hline Sea salt emission & Clarke et al. (2006) $10 \mathrm{~nm}-8 \mu \mathrm{m}$ & Clarke et al. (2006) $10 \mathrm{~nm}-8 \mu \mathrm{m}$ & Gong (2003) $35 \mathrm{~nm}-10 \mu \mathrm{m}$ \\
\hline Oxidants & Online chemistry calculation & $\begin{array}{l}\text { Average } \mathrm{OH}, \mathrm{HO}_{2} \text {, and } \mathrm{NO}_{3} \text { fields } \\
\text { from GISS } \mathrm{GCM} \text { and prognostic } \mathrm{H}_{2} \mathrm{O}_{2}\end{array}$ & $\begin{array}{l}\text { Average } \mathrm{OH}, \mathrm{H}_{2} \mathrm{O}_{2}, \mathrm{HO}_{2} \text {, } \\
\text { and } \mathrm{NO}_{3} \text { fields from TOMCAT }\end{array}$ \\
\hline In-cloud oxidation & $\begin{array}{l}\text { Combined oxidation in stratiform } \\
\text { and convective clouds; } \\
\text { assumed activation diameter of } 55 \mathrm{~nm}\end{array}$ & $\begin{array}{l}\text { Separately for stratiform } \\
\text { (activation diameter of } 82 \mathrm{~nm} \text { ) } \\
\text { and convective clouds } \\
\text { (activation diameter of } 33 \mathrm{~nm} \text { ) }\end{array}$ & $\begin{array}{l}\text { Combined oxidation in stratiform } \\
\text { and convective clouds; } \\
\text { assumed activation diameter of } 50 \mathrm{~nm}\end{array}$ \\
\hline
\end{tabular}

time step (generally $90 \mathrm{~s}$ ) for both nucleation and condensation. TOMAS treats the competition in a simpler way as discussed in Sect. 2.1. Another important assumption used in GLOMAP is the activation of particles with dry diameter larger than $0.05 \mu \mathrm{m}$. A summary of differences and similarities between GEOS-CHEM, GISS GCM-II', and GLOMAP are listed in Table 1.

\subsection{Model predictions}

\subsection{Sulfate mass prediction}

Table 2 presents the sulfur budget calculated from GEOSCHEM predictions using the size-resolved aerosol model developed in this work compared to the previous bulk aerosol model and the two other microphysics models. Note that evaporating $\mathrm{SO}_{2}$ from cloud droplets is assumed to have been oxidized to $\mathrm{SO}_{4}$ via aqueous chemistry (Sect. 2.1.6) and is, therefore, included in the $\mathrm{SO}_{2}+\mathrm{H}_{2} \mathrm{O}_{2}$ term in Table 2. Overall, the sulfur budget in this work changes only slightly with respect to the original GEOS-CHEM with bulk aerosol. The annual-average global burden of sulfate is increased from $0.34 \mathrm{Tg} \mathrm{S}$ to $0.38 \mathrm{Tg} \mathrm{S}$, and the lifetime is increased from 3.8 to 4.4 days. The implementation of microphysical processes affects the mass burden primarily by changing the depositional sinks. Size-resolved wet deposition, a major sink of sulfate mass and a major change from the bulk aerosol model, affects the sulfate mass budget by slowing down wet depositional lifetime by $11 \%$. The major reduction of in-cloud scavenging only impacts ultrafine mode particles, which are a small portion of the total sulfate mass, while the modification of below-cloud scavenging results in only little change due to the relative unimportance of the below-cloud scavenging. Also, sulfate dry deposition changes only slightly despite the new size-dependent dry deposition velocities shown in Fig. 1. This is because the predicted sulfate mass distribution is dominated by a mode centering on approximately $0.2 \mu \mathrm{m}$. At this size, the new dry deposition velocity equals that of the bulk aerosol model; thus the effect of the sizeresolved dry deposition is a modest $20 \%$ increase in dry depositional lifetime. 
Table 2. Global and annual-average sulfur budgets of three global models.

\begin{tabular}{|c|c|c|c|c|c|}
\hline & & GEOS-CHEM with TOMAS & GEOS-CHEM Bulk aerosol & GISS GCM-II' & GLOMAP \\
\hline \multicolumn{6}{|l|}{ DMS } \\
\hline Sources ( $\operatorname{Tg~} \mathrm{S} \mathrm{yr}^{-1}$ ) & Emissions & 13.6 & 13.6 & 10.6 & 12.6 \\
\hline Sinks $\left(\operatorname{Tg~S~yr}^{-1}\right)$ & DMS oxidation & 13.6 & 13.6 & 10.6 & 12.6 \\
\hline Burden $(\operatorname{Tg} S)$ & & 0.017 & 0.017 & 0.050 & 0.020 \\
\hline Lifetime (days) & & 0.46 & 0.46 & 1.7 & 0.58 \\
\hline \multicolumn{6}{|l|}{$\mathrm{SO}_{2}$} \\
\hline \multirow[t]{3}{*}{ Sources $\left(\mathrm{Tg} \mathrm{S} \mathrm{yr}{ }^{-1}\right)$} & Emissions & 67.8 & 67.8 & 70.8 & 77.6 \\
\hline & DMS oxidation & 12.3 & 12.2 & 9.5 & 12.6 \\
\hline & Total & 80.0 & 80.0 & 80.3 & 90.2 \\
\hline \multirow[t]{6}{*}{ Sinks $\left(\operatorname{Tg~S~yr}^{-1}\right)$} & $\mathrm{SO}_{2}+\mathrm{OH}$ & 8.7 & 8.5 & 14.6 & 10.8 \\
\hline & $\mathrm{SO}_{2}+\mathrm{H}_{2} \mathrm{O}_{2}$ & 20.9 & 21.0 & 28.4 & 30.5 \\
\hline & $\mathrm{SO}_{2}+\mathrm{O}_{3}$ & 0.7 & 0.7 & - & - \\
\hline & Dry deposition & 35.8 & 35.7 & 35.9 & 37.8 \\
\hline & Wet deposition & 14.1 & 14.1 & 1.5 & 11.4 \\
\hline & Total & 80.2 & 80.0 & 80.3 & 90.4 \\
\hline Burden $(\operatorname{Tg} S)$ & & 0.33 & 0.33 & 0.65 & 0.37 \\
\hline Lifetime (days) & & 1.5 & 1.5 & 2.9 & 1.5 \\
\hline Oxidation lifetime (days) & & 4.0 & 4.0 & 5.5 & 3.3 \\
\hline Dry deposition lifetime (days) & & 3.4 & 3.4 & 6.6 & 3.6 \\
\hline \multicolumn{6}{|l|}{$\mathbf{S O}_{4}^{2-}$} \\
\hline \multirow[t]{6}{*}{ Sources $\left(\mathrm{Tg} \mathrm{S} \mathrm{yr}^{-1}\right.$ ) } & Primary emissions & 2.0 & 2.0 & 2.0 & 2.4 \\
\hline & Gas-phase oxidation & - & 8.5 & - & - \\
\hline & Nucleation & 0.06 & - & 0.04 & 0.06 \\
\hline & $\mathrm{H}_{2} \mathrm{SO}_{4}$ condensation & 8.7 & - & 14.5 & 10.8 \\
\hline & Aqueous oxidation & 21.6 & 21.7 & 28.4 & 30.6 \\
\hline & Total & 32.3 & 32.2 & 45.0 & 43.9 \\
\hline \multirow[t]{3}{*}{ Sinks $\left(\operatorname{Tg~S~yr}^{-1}\right)$} & Dry deposition & 3.4 & 3.7 & 1.2 & 6.1 \\
\hline & Wet deposition & 28.8 & 28.6 & 43.8 & 37.7 \\
\hline & Total & 32.2 & 32.3 & 44.9 & 43.8 \\
\hline Burden $(\operatorname{Tg} \mathrm{S})$ & & 0.38 & 0.34 & 0.78 & 0.45 \\
\hline Lifetime (days) & & 4.4 & 3.8 & 6.3 & 3.8 \\
\hline Wet deposition lifetime (days) & & 4.8 & 4.3 & 6.5 & 4.4 \\
\hline \multicolumn{6}{|l|}{ MSA } \\
\hline Sources $\left(\operatorname{Tg~} \mathrm{S} \mathrm{yr}^{-1}\right)$ & DMS oxidation & 1.3 & 1.3 & 1.0 & - \\
\hline \multirow[t]{3}{*}{ Sinks $\left(\operatorname{Tg~S~yr}^{-1}\right)$} & Dry deposition & 0.09 & 0.09 & 0.2 & - \\
\hline & Wet deposition & 1.2 & 1.2 & 0.8 & - \\
\hline & Total & 1.3 & 1.3 & 1.0 & - \\
\hline Burden $(\operatorname{Tg} S)$ & & 0.017 & 0.017 & 0.020 & - \\
\hline Lifetime (days) & & 4.7 & 4.7 & 7.0 & - \\
\hline
\end{tabular}

\subsection{Sea-salt mass prediction}

Table 3 presents the sea-salt mass budget from this work in comparison with the earlier work by Alexander et al. (2005) and the intercomparison models. The Clarke et al. (2006) emission (this work) produces $78 \%$ more sea-salt than that of Monahan et al. (1986) (Alexander et al., 2005). Pierce and Adams (2006) also found the sea-salt emission from the Clarke et al. (2006) parameterization to be more than that from the Monahan et al. (1986) parameterization. Comparing our budget with that from Alexander et al. (2005) also highlights the effect of different size-dependent dry deposition treatments, with dry deposition being a dominant sink in their work. Though both versions of GEOS-CHEM have the size-dependent dry deposition scheme of Zhang et al. (2001), which can calculate a dry deposition velocity for any given size, Alexander et al. (2005) only had two modes of sea-salt while our size bins are more resolved, thus experiencing a greater range of deposition velocities. The coarse mode sea-salt in Alexander et al. (2005) is assumed to have a fast dry deposition velocity of a $\sim 10 \mu \mathrm{m}$ diameter particle. In our work, most of the coarse sea-salt mass centers around $7 \mu \mathrm{m}$ diameter, with a correspondingly lower dry deposition velocity (Fig. 1). Consequently, their coarsemode depositional lifetime is 0.7 days compared with 4.9 days in our work. As for wet deposition, we implemented size-dependent wet deposition criteria while Alexander et al. (2005) use the original wet deposition for bulk aerosol (Liu et al., 2001). The difference in wet depositional life- 
Table 3. Comparison of global and annual-average sea-salt budgets of four models.

\begin{tabular}{|c|c|c|c|c|c|c|c|}
\hline \multirow[b]{2}{*}{ Size range ${ }^{(b)}, \mu \mathrm{m}$} & \multicolumn{2}{|c|}{ GEOS-CHEM with TOMAS } & \multirow{2}{*}{$\begin{array}{c}\mathrm{AL05} \text { (a) } \\
0.2-20\end{array}$} & \multicolumn{2}{|c|}{ GISS GCM-II' with TOMAS } & \multicolumn{2}{|c|}{ GLOMAP } \\
\hline & $0.01-1.0$ & $1.0-10$ & & $0.01-1.0$ & $1.0-10$ & $0.003-1.0$ & $1.0-25$ \\
\hline \multicolumn{8}{|l|}{ Sources $\left(\operatorname{Tg~yr}^{-1}\right)$} \\
\hline Emissions & 130 & 9410 & 5370 & 100 & 7020 & 100 & 8310 \\
\hline \multicolumn{8}{|l|}{ Sinks $\left(\operatorname{Tg~yr}^{-1}\right)$} \\
\hline Dry deposition & 10 & 2220 & $3230^{(\mathrm{c})}$ & 10 & 4950 & 20 & 7240 \\
\hline Wet deposition & 120 & 7190 & $2150^{(\mathrm{c})}$ & 90 & 2070 & 90 & 1060 \\
\hline Total & 130 & 9410 & 5380 & 100 & 7020 & 110 & 8300 \\
\hline Burden (Tg) & 0.64 & 29.6 & 5.9 & 0.73 & 12.2 & 0.18 & 2.4 \\
\hline Lifetime (days) & 1.8 & 1.1 & $0.4^{(\mathrm{d})}$ & 2.7 & 0.6 & 0.6 & 0.1 \\
\hline
\end{tabular}

(a) Previous GEOS-CHEM model version without microphysics (Alexander et al., 2005) labeled AL05.

(b) Dry particle diameter, $D_{p}$.

(c) These are calculated from the provided lifetime and percentages of each deposition in Table 1 of Alexander et al. (2005).

(d) Lifetime of sea-salt with $D_{p}<2 \mu \mathrm{m}$ and $D_{p}>2 \mu \mathrm{m}$ are 1.3 , and 0.3 days, respectively.

time (50\% slower in this work compared to Alexander et al., 2005), however, is not mainly due to size-dependent wet deposition but rather to a combination of different precipitation in different simulation years and different locations of emissions. The combined result of these changes is that wet deposition is the dominant sink of coarse mode sea-salt in our sea-salt budget with an overall longer sea-salt lifetime.

\subsection{Aerosol number concentration prediction}

Figure 2 shows the predicted annual average $\mathrm{CN} 10$ and $\mathrm{CCN}(0.2 \%)$ concentrations $\left(\mathrm{cm}^{-3}\right.$ at STP conditions of $273 \mathrm{~K}$ and $1 \mathrm{~atm}$ ) in the lowest model layer. CN10 is defined here as a total number concentration of particles with diameters larger than $10 \mathrm{~nm}$. The $\mathrm{CCN}$ at $0.2 \%$ supersaturation is calculated as particles with diameter larger than $80 \mathrm{~nm}$, which accurately represents the corresponding activation diameter of sulfate, sea-salt, and mixtures thereof. The predictions show the expected features of high number concentrations over land and low over oceans. Predicted $\mathrm{CN} 10$ concentrations exceed $10000 \mathrm{~cm}^{-3}$ in the most polluted industrialized areas and are within the range of observed values of 5000 (Raes et al., 2000b) and $100000 \mathrm{~cm}^{-3}$ (Pandis et al., 1995). Outside the most polluted regions, continental CN10 concentrations mostly range from 500 to $5000 \mathrm{~cm}^{-3}$. For the marine boundary layer, $\mathrm{CN} 10$ concentrations are $100-500 \mathrm{~cm}^{-3}$, which are comparable with observations (Andreae et al., 1995; Clarke et al., 1987; Covert et al., 1996; Fitzgerald, 1991; Pandis et al., 1995; Raes et al., 2000b).

For $\mathrm{CCN}(0.2 \%)$ concentrations, the same trend of higher concentration over land than ocean is captured as well. $\mathrm{CCN}(0.2 \%)$ concentrations exceed $1000 \mathrm{~cm}^{-3}$ over the most polluted regions. Typical $\mathrm{CCN}(0.2 \%)$ concentrations over land are $100-1000 \mathrm{~cm}^{-3}$, while they range only from 10 to $100 \mathrm{~cm}^{-3}$ over oceans in agreement with expected values (Andreae et al., 1995).

Table 4 presents a global annual aerosol number budget. The size modes are categorized into ultrafine $(0.01-0.08 \mu \mathrm{m})$ and $\mathrm{CCN}(0.08-10 \mu \mathrm{m})$ modes. Note that coagulation is a sink for smaller particles and also a microphysical growth process adding particles into larger size bins, so coagulation is tabulated under both categories in Table 4. Source contributions to the ultrafine mode from nucleation and primary emission are comparable suggesting potential importance of both sources for $\mathrm{CCN}$ production. A major contributor of $\mathrm{CCN}$ is growth by aqueous oxidation. Coagulation is the dominant sink of ultrafine aerosols while wet deposition is the dominant sink of $\mathrm{CCN}$.

\subsection{Aerosol size distributions}

Figure 3 presents vertical profiles of the predicted aerosol number size distribution for two regions:

1. a polluted continental region, Eastern China $\left(100^{\circ} \mathrm{E}-120^{\circ} \mathrm{E}, 30^{\circ} \mathrm{N}-46^{\circ} \mathrm{N}\right)$

2. and a clean marine region, the South Pacific Ocean $\left(135^{\circ} \mathrm{W}-160^{\circ} \mathrm{W}, 14^{\circ} \mathrm{S}-30^{\circ} \mathrm{S}\right)$.

Vertical profiles emphasize how primary emissions, nucleation, and different aerosol growth mechanisms impact size distributions at different altitudes. In the upper troposphere, nucleation is the contributor as is evident in both Fig. 3a and $\mathrm{b}$ with peak ultrafine concentrations of up to $3000 \mathrm{~cm}^{-3}$. The air column over Eastern China shows higher nucleation rates with greater vertical extent than the South Pacific because there is more $\mathrm{SO}_{2}$ circulating in the northern hemisphere compared to the southern hemisphere. In the boundary layer, 
Table 4. Global and annual-average number budgets of three global models with size-resolved aerosol microphysics.

\begin{tabular}{|c|c|c|c|c|c|c|}
\hline \multirow[b]{2}{*}{ Size range*,$\mu \mathrm{m}$} & \multicolumn{2}{|c|}{ GEOS-CHEM-TOMAS } & \multicolumn{2}{|c|}{ GISS GCM-II'-TOMAS } & \multicolumn{2}{|c|}{ GLOMAP } \\
\hline & $0.01-0.08$ & $0.08-10$ & $0.01-0.08$ & $0.08-10$ & $0.003-0.08$ & $0.08-25$ \\
\hline \multicolumn{7}{|c|}{ Sources $\left(\mathrm{cm}^{-3} \mathrm{day}^{-1}\right)$} \\
\hline Primary emissions & 84 & 1.4 & 86 & 1.2 & 140 & 1.4 \\
\hline Nucleation & 56 & 0 & 37 & 0 & 1340 & 0 \\
\hline Total & 139 & 1.4 & 123 & 1.2 & 1480 & 1.4 \\
\hline \multicolumn{7}{|c|}{ Microphysical growth $\left(\mathrm{cm}^{-3}\right.$ day $\left.^{-1}\right)$} \\
\hline Condensation & -2.2 & 2.2 & -4.6 & 4.6 & -3.8 & 3.8 \\
\hline Aqueous oxidation & -4.5 & 4.5 & -8.7 & 8.7 & -7.8 & 7.8 \\
\hline Coagulation & - & 0.1 & - & 0.3 & - & 0.1 \\
\hline Total & -6.7 & 6.8 & -13.3 & 13.6 & -11.6 & 11.7 \\
\hline \multicolumn{7}{|l|}{ Sinks $\left(\mathrm{cm}^{-3}\right.$ day $\left.^{-1}\right)$} \\
\hline Dry deposition & 23 & 1.0 & 4 & 0.3 & 44 & 1.5 \\
\hline Wet deposition & 8 & 7.3 & 4 & 14.5 & 22 & 12.3 \\
\hline Coagulation & 101 & - & 102 & - & 1400 & - \\
\hline Total & 132 & 8.3 & 109 & 14.8 & 1466 & 13.8 \\
\hline $\left.\operatorname{Burden}(\mathrm{cm})^{-3}\right)$ & 607 & 35 & 535 & 62 & 3915 & 44 \\
\hline Lifetime (days) & 4.6 & 4.2 & 4.9 & 4.2 & 2.7 & 3.2 \\
\hline
\end{tabular}

* Size segregated by dry particle diameter, $D_{p}$
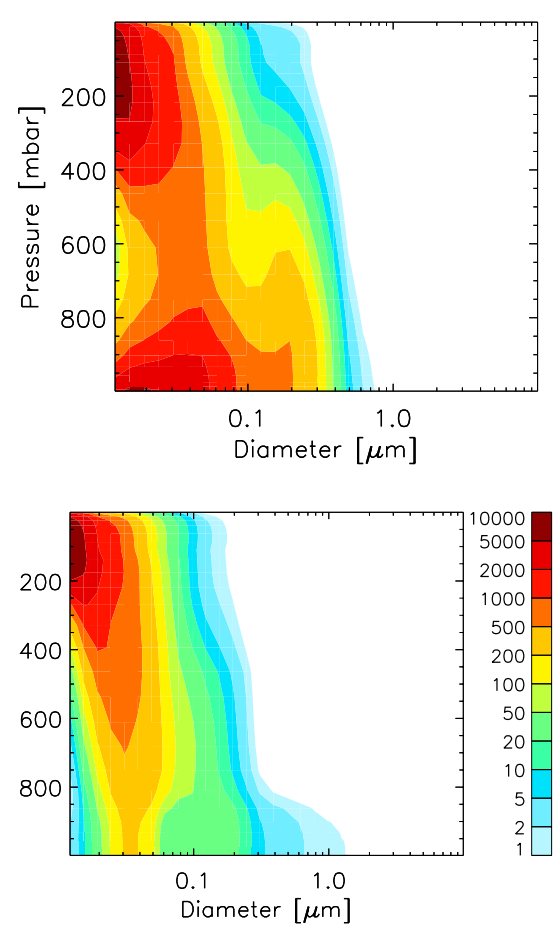

(b)

Fig. 3. GEOS-CHEM predicted annual average vertical profile of aerosol number size distribution $\left(\mathrm{cm}^{-3}\right.$ at STP conditions of $273 \mathrm{~K}$ and $1 \mathrm{~atm})$; (a) over Eastern China $\left(100^{\circ} \mathrm{E}-120^{\circ} \mathrm{E}, 30^{\circ} \mathrm{N}-46^{\circ} \mathrm{N}\right)$ and (b) South Pacific $\left(135^{\circ} \mathrm{W}-160^{\circ} \mathrm{W}, 14^{\circ} \mathrm{S}-30^{\circ} \mathrm{S}\right)$. primary emissions are the dominant source of aerosol number. Primary sulfate emission gives higher ultrafine number concentrations in the polluted continental region in Fig. 3a than the remote marine region in Fig. 3b. Similarly, primary sea-salt emission influences the size distribution in the Pacific Ocean with lower number concentration overall compared to primary sulfate emission. The bimodal structure in the boundary layer, most noticeable for the remote marine area, can be explained by in-cloud oxidation providing a source of sulfate mass and a growth mechanism for Aitken mode particles to grow to accumulation mode. Seasalt emission supplies significant mass to the coarse mode in the marine area, which explains the tail of the size distribution extending over $1 \mu \mathrm{m}$ size range in the remote marine region but not for the continental region. We can observe trends with altitude as nucleated particles grow as they subside. Freshly nucleated particles aloft become larger at lower altitudes and finally form a bimodal structure in the cloudprocessed BL. Subsidence and entrainment from the FT into the PBL is more important to CCN formation for the MBL than the polluted boundary layer.

\subsection{Comparison with field observations}

To test how realistic the model predictions are, model results can be compared with observational data. As a performance benchmark of currently available global models, the IPCC model comparison workshop reported average absolute errors (in percent) of modeled concentrations versus surface observations among different models for each aerosol 

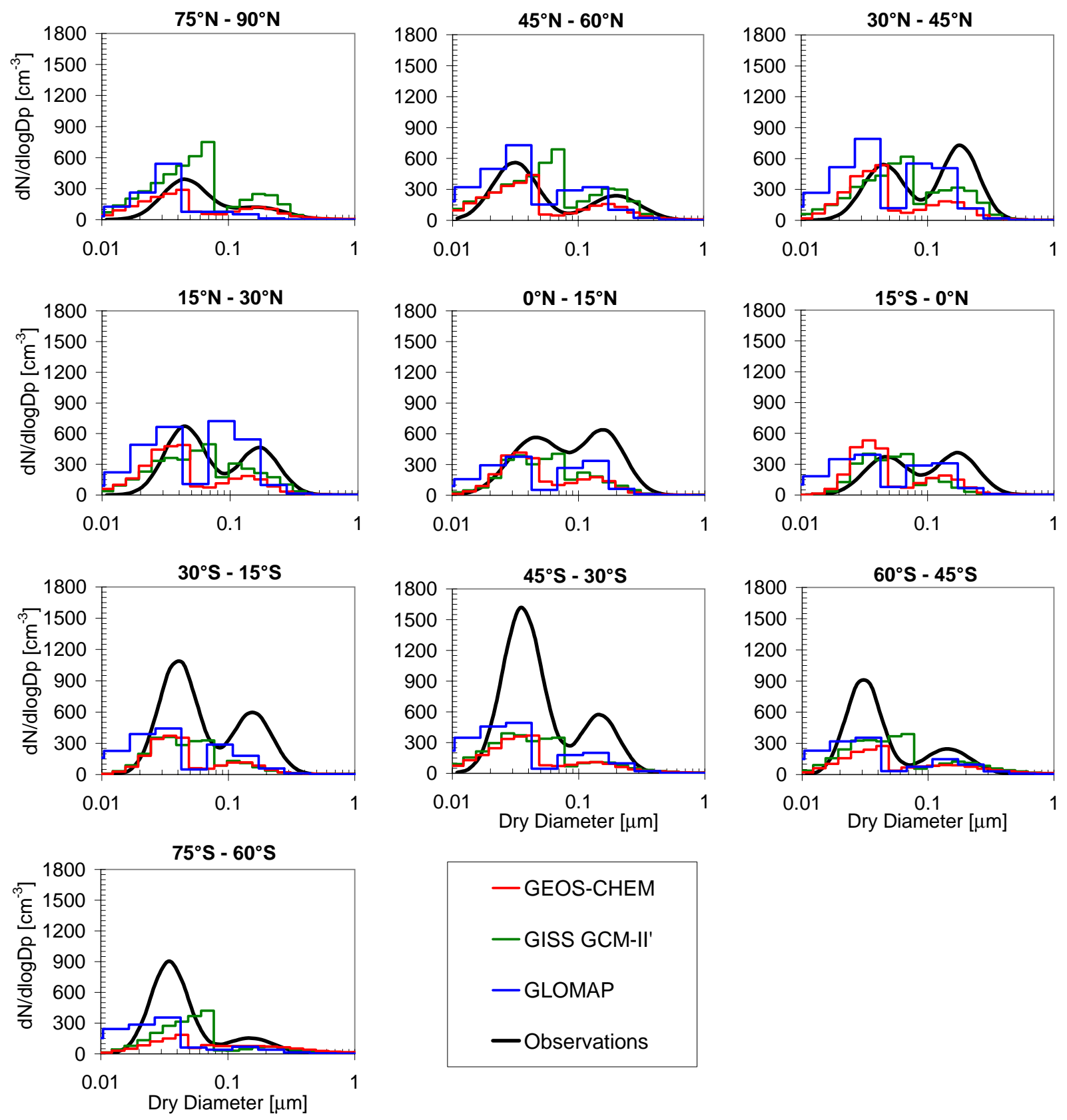

Fig. 4. Comparison of marine aerosol number distribution observations (black) at $273 \mathrm{~K}$ and $1 \mathrm{~atm}$ published in Heintzenberg et al. (2000) with predictions from GEOS-CHEM (red), GISS GCM-II'(Acosta et al.), and GLOMAP (blue). The modeled size distributions are taken from grid cells that represent the marine areas used to compile the Heintzenberg et al. (2000) data.

species, i.e., sulfate (26\%), sea-salt (46\%), dust (70\%), black carbon (179\%) and organic carbon (154\%)(IPCC, 2001). The COSAM experiment (Barrie et al., 2001) found intermodel differences in surface level seasonal mean of sulfate mixing ratios within $20 \%$ and up to a factor of 2 for $\mathrm{SO}_{2}$ mixing ratios compared to observations. These comparisons show the level of predictive skill among currently available global models for bulk aerosol mass.
For our model testing, we compare model results with the observational data of Heintzenberg at al. (2000). That data came from a large set of long-term sampling sites and various field campaigns and a variety of sampling instruments. The marine aerosol size distribution measurements were summarized by fitting the data to two lognormal modes for different latitudinal zones. Each latitude band is $15^{\circ}$ wide with no data between $75^{\circ} \mathrm{S}-90^{\circ} \mathrm{S}$ and $60^{\circ} \mathrm{N}-75^{\circ} \mathrm{N}$. To focus on marine aerosol, we exclude some of our continental grid cell data where it falls in their $15^{\circ} \times 15^{\circ}$ grid area. 


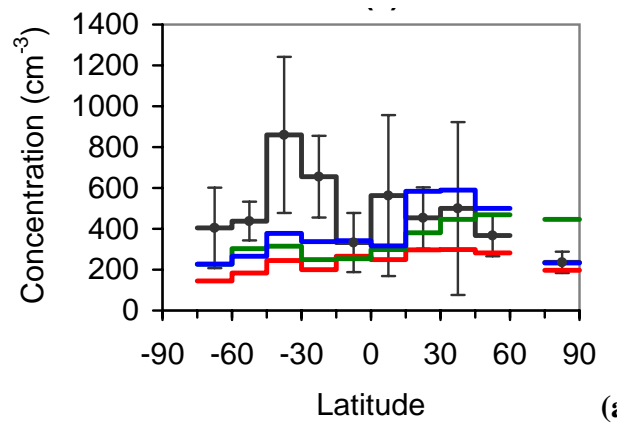

(a)

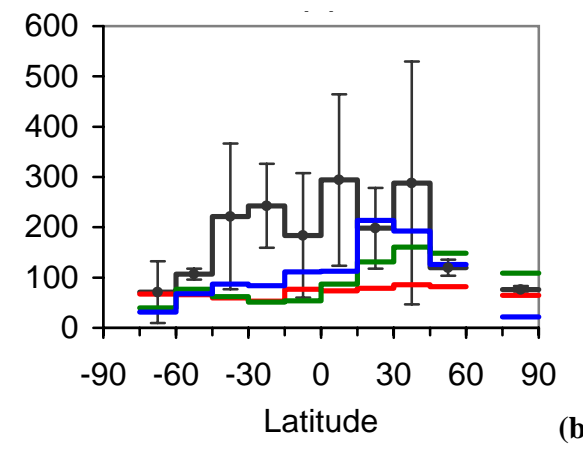

Fig. 5. Comparison of annual-average meridional distribution of observed (Heintzenberg et al., 2000) (black) and predicted by GEOS-CHEM (red), GISS GCM-II' (Acosta et al.), and GLOMAP (blue) for (a) CN10 and (b) accumulation mode aerosol concentrations at $273 \mathrm{~K}$ and $1 \mathrm{~atm}$. The error bars of the observations show one standard deviation range of variability. Negative latitudes denote the Southern Hemisphere.

Shown in Fig. 4, the bimodal structure of the Heintzenberg at al. (2000) data is captured in the predicted size distributions of all models. An important feature of the size distributions from each model is the minimum between modes, the location of which corresponds directly to the assumed activation diameters in aqueous oxidation (Sect. 2.1.1). In the case of GISS GCM-II', as a result of having two activation diameters, three modes appear in the size distributions of some latitudinal bands. The detailed size distributions from the models differ, and no model clearly outperforms the others.

Figure 5a shows the meridional distribution of predicted and observed CN10 concentrations. Global average absolute errors in $\mathrm{cm}^{-3}$ (and in percent) of predicted CN10 are 244 (45\%), $204(41 \%)$, and $176(32 \%) \mathrm{cm}^{-3}$ in GEOS-CHEM, GISS GCM-II', and GLOMAP, respectively. The latitudes where all models fail to predict within the range of the observed mean \pm one standard deviation are $15^{\circ} \mathrm{S}-60^{\circ} \mathrm{S}$. Over Southern Ocean regions, the marine aerosol should be dominated by sea spray emission when not affected much by carbonaceous aerosols from biomass burning. Therefore the $31 \%-72 \%$ underprediction in the $15^{\circ} \mathrm{S}-60^{\circ} \mathrm{S}$ latitude band in all models could be due to either the sea-salt emission or the lack of carbonaceous aerosols. Pierce et al. (2007) ex- plores the result of adding carbonaceous aerosols to a sulfatesea-salt model in GISS GCM-II' and found only a minor improvement, reducing model bias in $\mathrm{CN} 10$ prediction from $-63 \%$ to $-38 \%$ for $30^{\circ} \mathrm{S}-45^{\circ} \mathrm{S}$ region compared to the same observations. Spracklen et al. (2007) also had a similar finding.

Figure $5 \mathrm{~b}$ presents a meridional distribution of predicted $\mathrm{CCN}(0.2 \%)$ comparing with observed accumulation mode aerosol $\left(D_{p}>80 \mathrm{~nm}\right)$ concentrations used as surrogate for $\mathrm{CCN}(0.2 \%)$. Variability ranges are estimated standard deviation values of the accumulation mode aerosol shown in Fig. 3 of Heintzenberg at al. (2000). Global average absolute errors in $\mathrm{cm}^{-3}$ (and in percent) of predicted $\mathrm{CCN}(0.2 \%)$ are $109(50 \%), 101(51 \%)$, and $80 \mathrm{~cm}^{-3}(44 \%)$ in GEOSCHEM, GISS GCM-II', and GLOMAP, respectively. Overall, we find that all three models have encouragingly high skill in predicting $\mathrm{CN} 10$ and $\mathrm{CCN}(0.2 \%)$ concentrations in the marine boundary layer, with average errors in the $30 \%-$ $50 \%$ range, comparable to global model skill for predicting sulfate and sea-salt mass concentrations and much better than carbonaceous or mineral dust mass concentrations.

\subsection{Model intercomparison}

In this section, we compare GEOS-CHEM predictions with those from GISS GCM-II' and GLOMAP. The goal is to observe model behaviors and the level of agreement or disagreement, keeping in mind that the results are not from the same simulation year. The focus of this intercomparison is on $\mathrm{CN} 10$ and $\mathrm{CCN}(0.2 \%)$ predictions.

\subsection{Surface predictions}

We compare the predicted surface $\mathrm{CN} 10$ and $\mathrm{CCN}(0.2 \%)$ concentrations from the GISS GCM-II' and the GLOMAP models to those from GEOS-CHEM in terms of concentration ratios as shown in Fig. 6. The latitude-longitude map shows the spatial distribution of concentration ratios while the scatter plots present the level of agreement with GEOSCHEM. Over the southern part of Europe and Asia, GEOSCHEM predicts higher CN10 concentrations compared to both GLOMAP and GISS GCM-II'. This is because, among these models, only GEOS-CHEM uses the sulfur emission inventory with updated national emission and fuel use data. Although $\mathrm{SO}_{2}$ emissions globally and from developed countries are lower in the updated inventory, emissions from developing countries such as Thailand, Indonesia, Turkey, and Pakistan have increased by factors of 2 to 3 in 2000 with respect to 1985 . GLOMAP exhibits notably higher CN10 and particularly lower $\mathrm{CCN}(0.2 \%)$ over Antarctica compared to GEOS-CHEM and GISS GCM-II'. These high CN10 concentrations are due to high elevations over Antarctica with corresponding cold temperatures resulting in high nucleation rates calculated by GLOMAP especially in the winter months as presented in Fig. 1a of Spracklen et al. (2005b). The 
Table 5. Mean log of ratios and mean absolute log of ratios for $\mathrm{CN} 10$ and $\mathrm{CCN}(0.2 \%)$ of global models compared against GEOS-CHEM.

\begin{tabular}{lcccccccc}
\hline & \multicolumn{3}{c}{ CN10 Ratios } & \multicolumn{4}{c}{ CCN(0.2\%) Ratios } \\
& \multicolumn{2}{c}{ GISS GCM-II' } & \multicolumn{2}{c}{ GLOMAP } & \multicolumn{2}{c}{ GISS GCM-II' } & \multicolumn{2}{c}{ GLOMAP } \\
Regions * & ML & MAL & ML & MAL & ML & MAL & ML & MAL \\
\hline Polar & 3.1 & 3.1 & 3.3 & 3.3 & 1.7 & 1.8 & 0.3 & 4.2 \\
Marine & 1.4 & 1.5 & 1.5 & 1.6 & 1.1 & 1.5 & 1.3 & 1.7 \\
Continental & 1.3 & 1.7 & 1.0 & 1.6 & 1.3 & 1.5 & 1.4 & 1.6 \\
Polluted continental & 1.0 & 1.7 & 1.0 & 1.6 & 0.5 & 2.2 & 1.1 & 1.7 \\
All & 1.4 & 1.6 & 1.4 & 1.6 & 1.2 & 1.5 & 1.3 & 1.7 \\
\hline
\end{tabular}

\footnotetext{
* Regions are categorized by typical number concentrations of each region in GEOS-CHEM prediction.

- CN10 concentration ranges are: $<100,100-500,500-5000$, and $>5000 \mathrm{~cm}^{-3}$ (at $273 \mathrm{~K}$ and $1 \mathrm{~atm}$ ).

- $\mathrm{CCN}(0.2 \%)$ concentration ranges are: $<25,25-100,100-1000$, and $>1000 \mathrm{~cm}^{-3}$.
}

limited availability of condensable vapor means that these particles do not grow significantly to become $\mathrm{CCN}(0.2 \%)$. Elevated ultrafine concentrations over the Antarctic surface is a behavior that GLOMAP exhibits but not present in TOMAS as shown in Fig. 7. Figure 6 also presents scatter plots comparing surface $\mathrm{CN} 10$ and $\mathrm{CCN}(0.2 \%)$ predictions from model pairs. Comparisons of GEOS-CHEM against GISS GCM-II' and GLOMAP do not exhibit significantly different trends except in specific regions, e.g. $\mathrm{CCN}(0.2 \%)$ in polar regions.

The level of agreement of surface prediction is summarized in Table 5 as area-weighted mean $\log (\mathrm{ML})$ of ratios and mean absolute log (MAL) of ratios, which are calculated as follows,

$$
\log M L=\frac{1}{N} \sum_{i=1}^{N} \log x_{i}
$$

and

$$
\log M A L=\frac{1}{N} \sum_{i=1}^{N}\left|\log x_{i}\right|
$$

where $x_{i}$ is a ratio of concentrations from a model pair at grid box $i$ and $N$ is the number of grid boxes. The ratios are categorized into four different regions based on the CN10 and $\mathrm{CCN}(0.2 \%)$ concentrations predicted by GEOS-CHEM. The resulting regions can be loosely described as "polluted continental", "continental", "marine", and "polar". ML of ratios is indicative of the ratio of burden over the domain of interest, e.g. the surface, while MAL suggests the level of agreement between two models on average and MAL of 1.0 means perfect agreement. MAL of ratios of both CN10 and $\mathrm{CCN}(0.2 \%)$ fall within a factor of 2 except for over the poles in both models. Differences of predictions among models could be purely due to different wind fields distributing the same total amount; however, this is not the case. On average, the ML results show that both GISS GCM-II' and
GLOMAP predict $40 \%$ higher surface CN10 concentrations compared to GEOS-CHEM. For surface CCN(0.2\%), GISS GCM-II' and GLOMAP, compared with GEOS-CHEM, predict $20 \%$ and $30 \%$ higher concentrations on average, respectively. Lower concentrations of both $\mathrm{CN} 10$ and $\mathrm{CCN}(0.2 \%)$ in GEOS-CHEM are attributable to the use of updated emission inventories with lower sulfur emissions.

Table 5 shows that GEOS-CHEM CCN(0.2\%) predictions are slightly closer to those from the GISS GCM II' than GLOMAP. Otherwise, despite sharing the common TOMAS aerosol microphysics, the overall differences between GEOS-CHEM and GISS GCM II' are generally as large as the differences between GEOS-CHEM and GLOMAP. Therefore, the intercomparison does not show obvious behaviors influenced by meteorology or aerosol microphysics alone but suggests that meteorological fields are as important to the aerosol number predictions as model chemistry and microphysical schemes. Also the differences are higher on a monthly average basis (not shown), which reinforces the need to simulate accurately at specific times using the assimilated meteorology.

\subsection{Zonal average predictions}

Figure 7 shows the annual and zonal average CN10 and $\mathrm{CCN}(0.2 \%)$ predictions at STP conditions from the three models and zonal average nucleation mode $(1-10 \mathrm{~nm})$ concentrations from GLOMAP. For GEOSCHEM results, we only show predictions below the annual average tropopause above which aerosol microphysics was not simulated. For CN10 concentrations, features evident in all models are the elevated CN10 concentrations in the upper troposphere because of nucleation and the high CN10 from surface primary emissions centering at about $40^{\circ} \mathrm{N}-50^{\circ} \mathrm{N}$. The low temperatures, low particle surface area, and high relative humidity in the equatorial upper troposphere create ideal conditions for binary nucleation. However, while all models predict high CN10 concentrations in the upper 
(a)
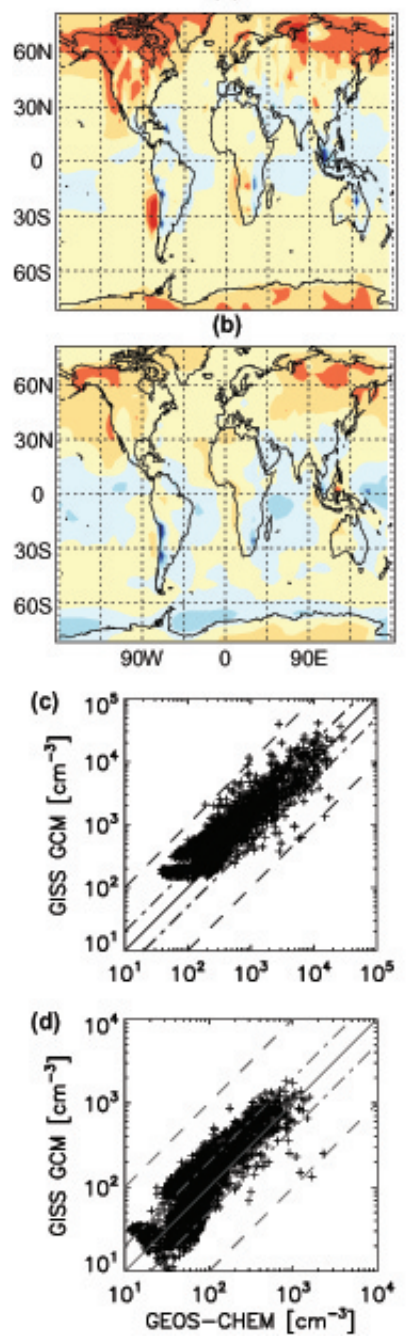

(e)
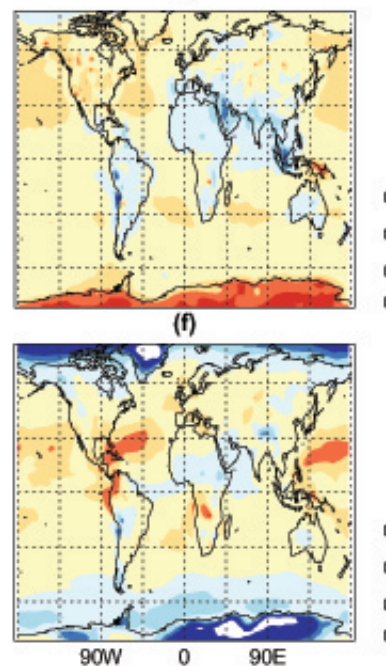

(g)

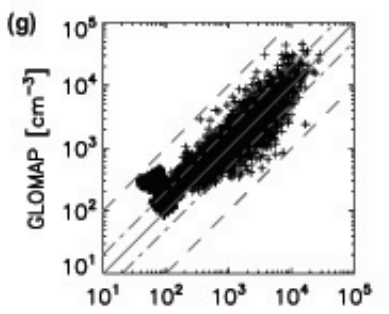

(h)

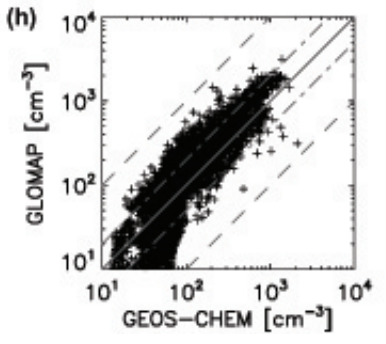

Fig. 6. Ratios of predicted annual average number concentrations in the lowest model layer for GISS GCM-II'/GEOS-CHEM; (a) CN10 ratios and (b) CCN $(0.2 \%)$ ratios. Comparison of GISS GCM-II' prediction versus GEOS-CHEM prediction for (c) $\mathrm{CN} 10$ and (d) $\mathrm{CCN}(0.2 \%)$ concentrations. (e)-(h) same as (a)-(d) but for ratios and comparison of GLOMAP against GEOS-CHEM. The scatter plot includes a 1:1 line (solid), 2:1 and 1:2 lines (dashed-dotted), and 10:1 and 1:10 lines (dashed). Each data point represents data from one model grid box.

troposphere because of nucleation, there are differences in the locations and magnitudes of the peak concentrations. All models exhibit major nucleation in the equatorial upper troposphere, while GLOMAP also shows its maximum nucleation region extending to the northern mid-latitudes, as shown in Fig. 7g. Also, the peak CN10 occurs at different altitudes for each model, i.e. 150 and $100 \mathrm{mbar}$ for GEOS-CHEM and GISS GCM-II', respectively, and 100 and 300 mbar for GLOMAP; this could be because the different temperatures and relative humidity predicted in each model as well as the ability of different vertical transport schemes of each model to transport $\mathrm{SO}_{2}$ up to the free troposphere. In Fig. 7a, GEOS-CHEM predicts high CN10 concentration across the tropopause spreading into the stratosphere unlike CN10 predicted by GLOMAP, in which the high concentrations are confined by the tropopause being higher over the equator and descending toward both poles (Fig. 7c and g).

For $\mathrm{CCN}(0.2 \%)$ concentrations, GEOS-CHEM predicts the most widespread and deepest $\mathrm{CCN}(0.2 \%)$ minimum in the tropical upper troposphere, shown in Fig. 7d. The low aerosol surface area in this region contributes to the higher nucleation rates and CN10 concentrations already mentioned in Fig. 7a. GISS GCM-II' has the tendency to transport heavily polluted air toward the North Pole as evidenced by the higher $\mathrm{CCN}(0.2 \%)$ concentrations there.

Model-to-model differences increase as one moves upward from the surface; a similar result was found in the COSAM intercomparison of sulfur models (Lohmann et al., 2001). In the free troposphere, predicted $\mathrm{CN} 10$ and $\mathrm{CCN}(0.2 \%)$ concentrations among models can differ by an order of magnitude or more. For example, at $300 \mathrm{mb}$ level (not shown) GISS GCM-II' compared against GEOS-CHEM has the MAL of ratios of $\mathrm{CCN}(0.2 \%)$ of 2.8 and a maximum ratio of 20 with a large region of high values $(>10)$ over India and a region of low values $(<0.1)$ over Southeast Asia. Similarly, the MAL of CCN( $0.2 \%)$ ratios of GLOMAP to GEOSCHEM predictions at $300 \mathrm{mb}$ is 2.3 with a maximum of 15.5 . Different vertical transport schemes definitely play a part in the discrepancies. Several studies in the past evaluated vertical transport of each model using one or more or the combination of ${ }^{222} \mathrm{Rn},{ }^{210} \mathrm{~Pb}$, and ${ }^{7} \mathrm{Be}$ as tracers (Allen et al., 1996; Jacob et al., 1997; Koch et al., 1996; Liu et al., 2001; Lohmann et al., 2001; Rind and Lerner, 1996; Stockwell and Chipperfield, 1999) and yet vertical transport remains an important uncertainty. Nevertheless, all models were able to reproduce measured vertical profile concentrations to within a factor of five. Though we cannot postulate the exact causes of discrepancy here, several factors definitely contribute including microphysics schemes, precipitations, and meteorological inputs.

\subsection{Global budgets}

Analyzing global aerosol mass and number budgets provides some insights into how factors such as meteorology, microphysics, and chemistry, affect the prediction of $\mathrm{CN}$ and $\mathrm{CCN}$ concentrations and their lifetimes. Tables 2, 3, and 4 present global annual budgets of sulfur, sea-salt, and aerosol number, respectively, from each model in our model intercomparison.

The sulfur budgets in Table 2 show that, for all of the sulfur-containing species, GISS GCM-II' has higher burdens and longer lifetimes than those of GLOMAP and GEOSCHEM. For sulfate, all models have similar source contribution profiles (percentage of each source) although GISS GCM-II' shows slightly more condensation. The effect of different oxidant fields is demonstrated in the oxidation 
(a)

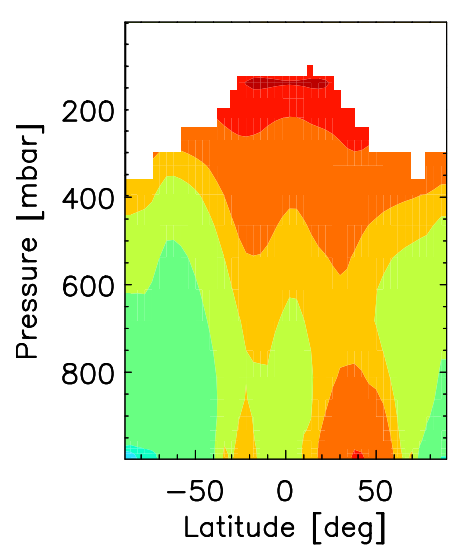

(d)

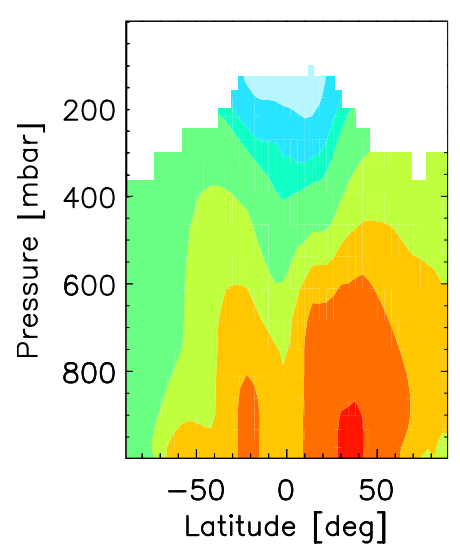

(b)

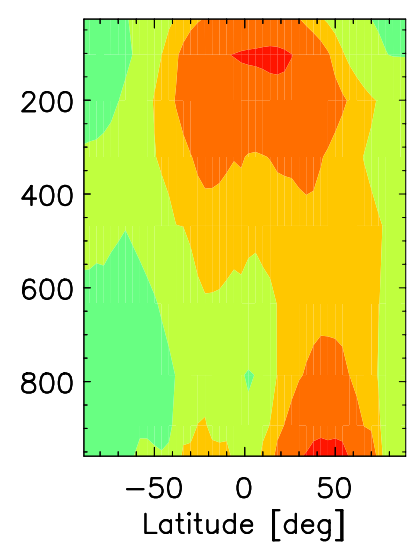

(e)

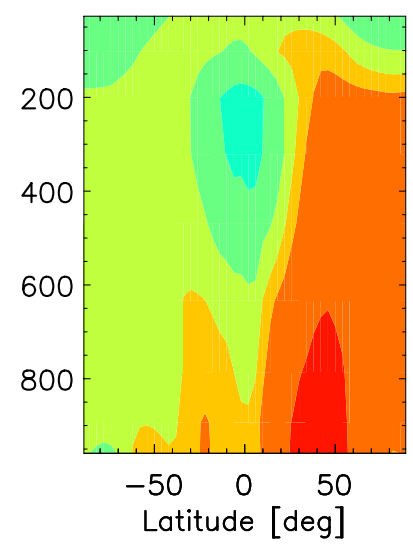

(g)

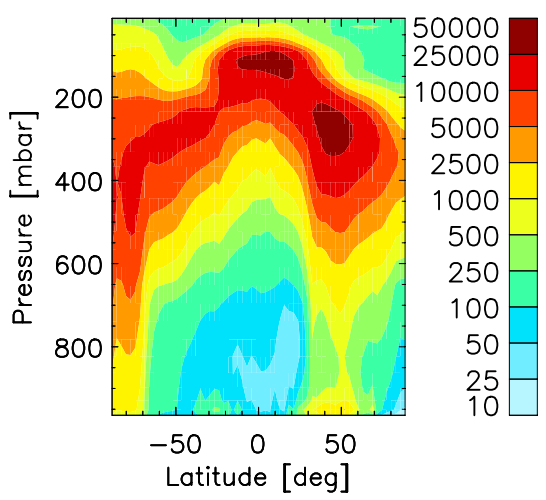

(c)

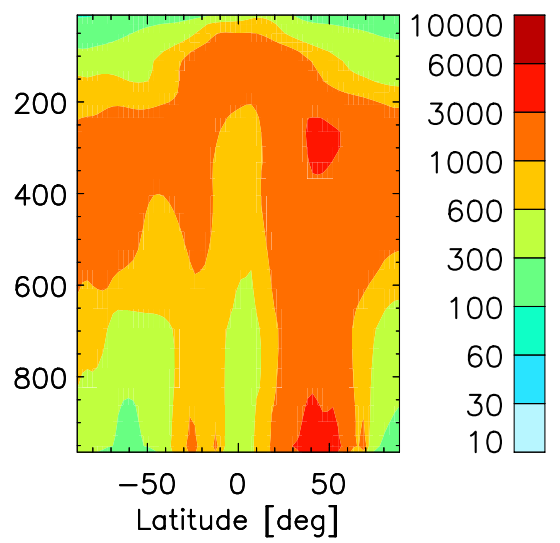

(f)

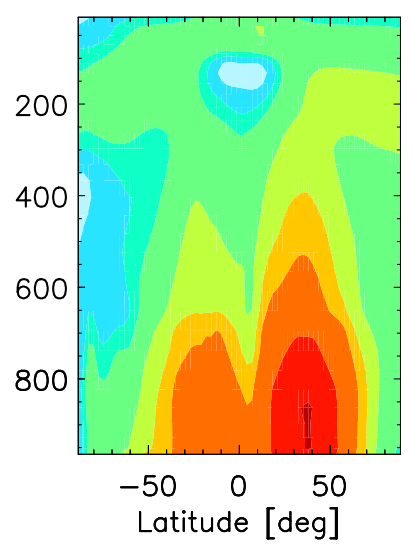

Fig. 7. Zonal average CN10 concentrations ( $\mathrm{cm}^{-3}$ at $273 \mathrm{~K}$ and $1 \mathrm{~atm}$ ) from the (a) GEOS-CHEM, (b) GISS GCM-II', and (c) GLOMAP models. (d)-(f) same as (a)-(c) but for zonal average $\mathrm{CCN}(0.2 \%)$. (g) GLOMAP nucleation mode (1-10 nm) number concentration.

lifetime of $\mathrm{SO}_{2}$ showing that GLOMAP has the most abundant oxidants in regions with high $\mathrm{SO}_{2}$, both $\mathrm{OH}$ and $\mathrm{H}_{2} \mathrm{O}_{2}$, for reacting with $\mathrm{SO}_{2}$ while GISS GCM-II' has the slowest oxidation. The fact that GLOMAP is the only model in this intercomparison that uses prescribed average $\mathrm{H}_{2} \mathrm{O}_{2}$ con- centration and has the fastest oxidation agrees with the findings by Roelofs et al. $(1998 ; 2001)$ that models applying full chemistry or prognostic approach tend to have lower sulfate oxidation by $\mathrm{H}_{2} \mathrm{O}_{2}$ because they represent oxidant limited conditions more realistically. Also, DMS oxidation in GISS 
GCM-II' is about three times slower compared to other models and the majority of the difference in lifetime is the different oxidants while the different rate constants over different temperatures contribute to about $10 \%$ discrepancy. Nevertheless DMS emissions between models are similar therefore the $\mathrm{SO}_{2}$ production from DMS is also similar.

Dry deposition is the most important sink for $\mathrm{SO}_{2}$ and is modeled using similar resistant-in-series approach in all models. Despite similar treatment of gas dry deposition, the GISS GCM-II' shows a higher dry deposition lifetime compared to GEOS-CHEM and GLOMAP. This difference can be attributed to the lower vertical resolution in GISS GCMII' and is consistent with the findings in the COSAM intercomparison that models with higher vertical resolution apparently weaken mixing between the boundary layer and the free troposphere, thereby enhancing the impact of dry deposition of sulfur species (Roelofs et al., 2001).

For $\mathrm{SO}_{4}^{2-}$ sources, transformation via aqueous chemistry is the largest contribution (67-70\%). Despite having the slowest oxidation, GISS GCM-II' has the largest $\mathrm{SO}_{4}^{2-}$ source because its weaker dry deposition than other models results in more $\mathrm{SO}_{2}$ available for oxidation. As for $\mathrm{SO}_{4}^{2-}$ sinks, all models consistently indicate that wet deposition is dominant. The $\mathrm{SO}_{4}^{2-}$ wet deposition lifetime, summarizing the effects of different cloud and precipitation fields in each model, is shown in Table 2. GLOMAP has the most active removal by precipitation and GISS GCM-II' has the slowest wet removal despite the largest removal rate.

Comparison of sea-salt budgets in Table 3 points to discrepancies due to meteorology and dry deposition schemes. Because GEOS-CHEM and GISS GCM-II' use the same emissions parameterization, total sea-salt emissions in each model represents the average strength of their winds. Regarding dry deposition, GEOS-CHEM's coarse-mode dry deposition is significantly slower than other models; dry deposition lifetime of GEOS-CHEM, GISS GCM-II', and GLOMAP are 4.9, 0.9, and 0.1 days, respectively. Coarsemode dry deposition velocities in our work are around an order of magnitude smaller than those in GISS GCM-II', hence the slower dry deposition. The size-dependent dry deposition scheme in GLOMAP is the same as GEOS-CHEM. Therefore, the difference results from different sea-salt size distributions of the respective emissions parameterizations combined with GLOMAP's inclusion of particles up to $25 \mu \mathrm{m}$ leading to greater range of dry deposition velocities (see trend in Fig. (1). Global budgets show that GEOSCHEM has the highest sea-salt burden among all models, although the contribution to global $\mathrm{CCN}(0.2 \%)$ is modest since the majority of sea-salt mass is in the coarse-mode and translates to few particles.

Presented in Table 4, in this intercomparison, GEOSCHEM predicts the lowest global-average $\mathrm{CCN}(0.2 \%)$ concentration (burden) of $35 \mathrm{~cm}^{-3}$ compared to 62 and $44 \mathrm{~cm}^{-3}$ in GISS GCM-II' and GLOMAP, respectively. For ease of interpretation, the global burden has been converted to concentration using a tropospheric volume based on an average tropopause height of $12 \mathrm{~km}$. The aerosol number budget shows that GEOS-CHEM has approximately a factor of 2 lower microphysical growth compared to other models, which is the reason for low global $\operatorname{CCN}(0.2 \%)$. Moreover, effective scavenging in the tropical convection in GEOSCHEM contributes to low tropical UT $\mathrm{CCN}(0.2 \%)$ shown in Fig. 7d. Globally averaged, however, GEOS-CHEM has slower removal compared to other models; wet depositional lifetimes of $\mathrm{CCN}(0.2 \%)$ are 4.8, 4.3, and 3.6 days for GEOSCHEM, GISS GCM-II', and GLOMAP, respectively. Again faster wet removal in GLOMAP suggests that year 1996 may be a wetter year than 2001 of GEOS-CHEM simulation. Low microphysical growth in GEOS-CHEM is attributable to it having the lowest available sources of sulfate due to effective $\mathrm{SO}_{2}$ loss by dry deposition. In Table 2 , total $\mathrm{SO}_{2}$ oxidation sinks, equivalently the source of sulfate for microphysical growth, are 30.3, 43.0, and 41.4 $\mathrm{Tg} \mathrm{S} \mathrm{yr}^{-1}$ in GEOS-CHEM, GISS GCM-II', and GLOMAP, respectively. The higher nucleation source in GEOS-CHEM than in GISS GCM-II' shown in Table 4, despite the lower source from $\mathrm{SO}_{2}+\mathrm{OH}$, reinforces the finding that there are fewer existing particles in the upper equatorial troposphere.

CCN lifetimes (Table 4) of 4.2, 4.2, and 3.2 days for GEOS-CHEM, GISS GCM-II', and GLOMAP, respectively, are comparable. For particles smaller than $0.08 \mu \mathrm{m}$, GEOSCHEM and GISS GCM-II' predict very close lifetimes as well. Not surprisingly, GLOMAP has a much shorter lifetime of 2.7 days for ultrafine particles than the other two models; given that GLOMAP's lower size limit includes smaller particles in the $1-10 \mathrm{~nm}$ size range, their ultrafine particles are subjected to very fast coagulation.

\section{Conclusions}

Discussion and conclusions The size-resolved aerosol microphysics module, TOMAS, has been introduced to the GEOSCHEM chemical-transport model. Because GEOS-CHEM is driven by assimilated meteorology, it will be an ideal vehicle for testing the TOMAS microphysics simulation, especially against field campaign data. Advantages of a two-moment sectional method are high size resolution, accurate and efficient representation of both mass and number, and conservation of aerosol number, which are essential to our ultimate goal of improving the indirect radiative forcing estimates. Microphysical processes include condensation/evaporation, coagulation, and nucleation. Apart from introducing microphysical processes to the model, existing processes, namely emission, advection, convection, chemistry, and deposition, were modified to handle aerosol size distributions properly. The aerosol size distribution is represented by size bins segregated by dry aerosol mass covering the range of about 
$10 \mathrm{~nm}$ to $10 \mu \mathrm{m}$ dry diameter. Sulfate and sea-salt aerosols are included in the current microphysics model.

Qualitative features of atmospheric aerosols are well simulated, e.g. higher aerosol concentrations over land than oceans, the nucleation dominated size distribution in the upper troposphere, the primary emission dominated size distribution over source regions at surface, and the bimodal size distribution over the MBL resulting from in-cloud sulfur oxidation. Additionally, as a benchmark for the current state of global microphysics model development, we perform a model intercomparison with GISS GCM-II' and GLOMAP models, which are global models with two-moment aerosol microphysics. A comparison of annual-average MBL CN10 and $\mathrm{CCN}(0.2 \%)$ predictions from each model to a compilation of MBL aerosol observations of Heintzenberg et al. (2000) show reasonably good predictive skill with annually averaged absolute errors of 30-50\%. However, all models underpredict $\mathrm{CN} 10$ and $\mathrm{CCN}(0.2 \%)$ over the Southern Ocean by $45-57 \%$ suggesting a common point for improvement in sea-salt emissions. Moreover, all overpredict $\mathrm{CN} 10$ concentrations between $45^{\circ}$ and $60^{\circ} \mathrm{N}$ suggesting potential weakness in the common sulfate primary emission. These common model errors point out the needs for future observations in the Southern Ocean to better constrain marine aerosol source and in the Northern hemisphere polluted latitudes to improve the estimates of size-resolved emission and rates of aging. Overall, model skill for predicting CN10 and $\mathrm{CCN}(0.2 \%)$ is comparable with global model skill in predicting sulfate and sea-salt mass and much better than those predicting carbonaceous aerosols and dust mass.

Model intercomparison at the surface shows agreement generally within a factor of 2 for $\mathrm{CN} 10$ and $\mathrm{CCN}(0.2 \%)$ predictions except over the poles; GISS GCM-II' and GLOMAP on average predict $\mathrm{CN} 10$ and $\mathrm{CCN}(0.2 \%)$ within $60 \%$ and $50 \%-70 \%$ to GEOS-CHEM prediction, respectively. Major differences at the surface are due to different transport and emissions. GEOS-CHEM also predicts lower surface concentrations of $\mathrm{CN} 10$ and $\mathrm{CCN}(0.2 \%)$ than the other two models. Zonal average comparison reveals discrepancies in location and concentration of peak CN10 in the upper troposphere that is a feature of nucleation. These intermodel discrepancies at altitudes point out the need for more and longer term aircraft measurements of aerosol microphysical properties. Global annually averaged budgets show that GEOS-CHEM predicts lowest $\mathrm{CCN}(0.2 \%)$ among the three models due to a factor of 2 lower microphysical growth than other models. The level of agreement of each model paired with GEOS-CHEM in this intercomparison suggests that meteorological differences (e.g. winds, precipitation) are as significant as differences from chemistry (e.g. oxidants) and microphysical schemes. This emphasizes the need to have accurate meteorology and realistic oxidants and clouds representation that will enable comparison with observations and evaluation of aerosol microphysical model. Future work will add other aerosol species to GEOS-CHEM's microphysical simulation. Then aerosol predictions can be tested with field campaign observations such as the ACE-Asia experiment, which will potentially lead to improvement in our simulation of the aerosol microphysics and ultimately the estimate of the aerosol indirect effects.

Acknowledgements. We thank Jeffrey Pierce for providing model results and support on the analysis. We also want to thank Rokjin Park and Bob Yantosca for supports on GEOS-CHEM model. This work was supported by funding from the National Aeronautics and Space Administration (Award NNG04GE86G) and from The Office of The Civil Service Commission under The Royal Thai Government.

Edited by: K. Lehtinen

\section{References}

Adams, P. J. and Seinfeld, J. H.: Predicting global aerosol size distributions in general circulation models, J. Geophys. Res.Atmos., 107, 4370, doi:10.1029/2001JD001010, 2002.

Adams, P. J. and Seinfeld, J. H.: Disproportionate impact of particulate emissions on global cloud condensation nuclei concentrations, Geophys. Res. Lett., 30, 1239, doi:10.1029/2002GL016303, 2003.

Albrecht, B. A.: Aerosols, Cloud Microphysics, and Fractional Cloudiness, Science, 245, 1227-1230, 1989.

Alexander, B., Park, R. J., Jacob, D. J., Li, Q. B., Yantosca, R. M., Savarino, J., Lee, C. C. W., and Thiemens, M. H.: Sulfate formation in sea-salt aerosols: Constraints from oxygen isotopes, J. Geophys. Res.-Atmos., 110, D10307, doi:10.1029/2004JD005659, 2005.

Allen, D. J., Rood, R. B., Thompson, A. M., and Hudson, R. D.: Three-dimensional radon 222 calculations using assimilated meteorological data and a convective mixing algorithm, J. Geophys. Res.-Atmos., 101, 6871-6881, 1996.

Andreae, M. O., Elbert, W., and Demora, S. J.: Biogenic Sulfur Emissions and Aerosols over the Tropical South-Atlantic 3. Atmospheric Dimethylsulfide, Aerosols and Cloud Condensation Nuclei, J. Geophys. Res.-Atmos., 100, 11 335-11 356, 1995.

Barrie, L. A., Yi, Y., Leaitch, W. R., Lohmann, U., Kasibhatla, P., Roelofs, G. J., Wilson, J., McGovern, F., Benkovitz, C., Melieres, M. A., Law, K., Prospero, J., Kritz, M., Bergmann, D., Bridgeman, C., Chin, M., Christensen, J., Easter, R., Feichter, J., Land, C., Jeuken, A., Kjellstrom, E., Koch, D., and Rasch, P.: A comparison of large-scale atmospheric sulphate aerosol models (COSAM): overview and highlights, Tellus B, 53, 615-645, 2001.

Bates, T. S., Huebert, B. J., Gras, J. L., Griffiths, F. B., and Durkee, P. A.: International Global Atmospheric Chemistry (IGAC) project's first aerosol characterization experiment (ACE 1): Overview, J. Geophys. Res.-Atmos., 103, 16297-16318, 1998.

Bates, T. S., Quinn, P. K., Coffman, D. J., Johnson, J. E., Miller, T. L., Covert, D. S., Wiedensohler, A., Leinert, S., Nowak, A., and Neususs, C.: Regional physical and chemical properties of the marine boundary layer aerosol across the Atlantic during Aerosols99: An overview, J. Geophys. Res.-Atmos., 106, 20767-20 782, 2001. 
Bey, I., Jacob, D. J., Yantosca, R. M., Logan, J. A., Field, B. D., Fiore, A. M., Li, Q. B., Liu, H. G. Y., Mickley, L. J., and Schultz, M. G.: Global modeling of tropospheric chemistry with assimilated meteorology: Model description and evaluation, J. Geophys. Res.-Atmos., 106, 23 073-23 095, 2001.

Boucher, O. and Lohmann, U.: The Sulfate-Ccn-Cloud Albedo Effect - a Sensitivity Study with 2 General-Circulation Models, Tellus B, 47, 281-300, 1995.

Carpenter, R. L., Droegemeier, K. K., Woodward, P. R., and Hane, C. E.: Application of the Piecewise Parabolic Method (Ppm) to Meteorological Modeling, Mon. Weather Rev., 118, 586-612, 1990.

Charlson, R. J., Schwartz, S. E., Hales, J. M., Cess, R. D., Coakley, J. A., Hansen, J. E., and Hofmann, D. J.: Climate Forcing by Anthropogenic Aerosols, Science, 255, 423-430, 1992.

Chin, M., Rood, R. B., Lin, S. J., Muller, J. F., and Thompson, A. M.: Atmospheric sulfur cycle simulated in the global model GOCART: Model description and global properties, J. Geophys. Res.-Atmos., 105, 24 671-24 687, 2000.

Clarke, A. D., Ahlquist, N. C., and Covert, D. S.: The Pacific Marine Aerosol - Evidence for Natural Acid Sulfates, J. Geophys. Res.-Atmos., 92, 4179-4190, 1987.

Clarke, A. D., Owens, S. R., and Zhou, J. C.: An ultrafine seasalt flux from breaking waves: Implications for cloud condensation nuclei in the remote marine atmosphere, J. Geophys. Res.Atmos., 111, 2006.

Colella, P. and Woodward, P. R.: The Piecewise Parabolic Method (Ppm) for Gas-Dynamical Simulations, J. Comput. Phys., 54, 174-201, 1984.

Covert, D. S., Kapustin, V. N., Bates, T. S., and Quinn, P. K.: Physical properties of marine boundary layer aerosol particles of the mid-Pacific in relation to sources and meteorological transport, J. Geophys. Res.-Atmos., 101, 6919-6930, 1996.

Dana, M. T. and Hales, J. M.: Statistical Aspects of Washout of Polydisperse Aerosols, Atmos. Environ., 10, 45-50, 1976.

Easter, R. C., Ghan, S. J., Zhang, Y., Saylor, R. D., Chapman, E. G., Laulainen, N. S., Abdul-Razzak, H., Leung, L. R., Bian, X. D., and Zaveri, R. A.: MIRAGE: Model description and evaluation of aerosols and trace gases, J. Geophys. Res.-Atmos., 109, D20210, doi:10.1029/2004JD004571, 2004.

Fairlie, T. D., Jacob, D., and Park, R. J.: A simulation of transpacific transport of mineral dust from Asia during spring 2001: Evaluation of results from GEOS-CHEM with ground-based, aircraft and satellite measurements, Eos Trans. AGU, 85(17), Abstract A31B-07, 2004.

Fitzgerald, J. W.: Marine Aerosols - a Review, Atmos. Environ. A-Gen., 25, 533-545, 1991.

Ghan, S., Easter, R., Hudson, J., and Breon, F. M.: Evaluation of aerosol indirect radiative forcing in MIRAGE, J. Geophys. Res.Atmos., 106, 5317-5334, 2001.

Giorgi, F. and Chameides, W. L.: Rainout lifetimes of highly soluble aerosols and gases as inferred from Simulations with a general-circulation model, J. Geophys. Res.-Atmos., 91, $14367-$ $14376,1986$.

Gong, S. L.: A parameterization of sea-salt aerosol source function for sub- and super-micron particles, Global Biogeochem. Cy., 17, 1097-1103, 2003.

Heintzenberg, J., Covert, D. C., and Van Dingenen, R.: Size distribution and chemical composition of marine aerosols: a compila- tion and review, Tellus B, 52, 1104-1122, 2000.

Herzog, M., Weisenstein, D. K., and Penner, J. E.: A dynamic aerosol module for global chemical transport models: Model description, J. Geophys. Res.-Atmos., 109, D18202, doi:10.1029/2003JD004405, 2004.

Huebert, B. J., Bates, T., Russell, P. B., Shi, G. Y., Kim, Y. J., Kawamura, K., Carmichael, G., and Nakajima, T.: An overview of ACE-Asia: Strategies for quantifying the relationships between Asian aerosols and their climatic impacts, J. Geophys Res.-Atmos., 108, 8633, doi:10.1029/2003JD003550, 2003.

Intergovernmental Panel on Climate Change(IPCC): Climate Change 2001, Third Assessment Report, 2001.

Intergovernmental Panel on Climate Change(IPCC): Climate Change 2007: The Physical Science Basis: Summary for Policymakers, Fourth Assessment Report, 2007.

Jacob, D. J., Prather, M. J., Rasch, P. J., Shia, R. L., Balkanski, Y. J., Beagley, S. R., Bergmann, D. J., Blackshear, W. T., Brown, M., Chiba, M., Chipperfield, M. P., deGrandpre, J., Dignon, J. E., Feichter, J., Genthon, C., Grose, W. L., Kasibhatla, P. S., Kohler, I., Kritz, M. A., Law, K., Penner, J. E., Ramonet, M., Reeves, C. E., Rotman, D. A., Stockwell, D. Z., VanVelthoven, P. F. J., Verver, G., Wild, O., Yang, H., and Zimmermann, P.: Evaluation and intercomparison of global atmospheric transport models using Rn-222 and other short-lived tracers, J. Geophys. Res.-Atmos., 102, 5953-5970, 1997.

Jacob, D. J., Crawford, J. H., Kleb, M. M., Connors, V. S., Bendura, R. J., Raper, J. L., Sachse, G. W., Gille, J. C., Emmons, L., and Heald, C. L.: Transport and Chemical Evolution over the Pacific (TRACE-P) aircraft mission: Design, execution, and first results, J. Geophys. Res.-Atmos., 108, 1-19, 2003.

Jacobson, M. Z., Turco, R. P., Jensen, E. J. and Toon, O. B.: Modeling Coagulation among Particles of Different Composition and Size, Atmos. Environ., 28, 1327-1338, 1994.

Jacobson, M. Z.: Numerical techniques to solve condensational and dissolutional growth equations when growth is coupled to reversible reactions, Aerosol Sci. and Tech., 27, 491-498, 1997a.

Jacobson, M. Z.: Development and application of a new air pollution modeling system. 2. Aerosol module structure and design, Atmos. Environ., 31, 131-144, 1997 b.

Jaecker-Voirol, A. and Mirabel, P.: Heteromolecular nucleation in the sulfuric acid-water system, Atmos. Environ., 23, 2053-2057, 1989.

Jones, A., Roberts, D. L., and Slingo, A.: A Climate Model Study of Indirect Radiative Forcing by Anthropogenic Sulfate Aerosols, Nature, 370, 450-453, 1994.

Kiehl, J. T., Schneider, T. L., Rasch, P. J., Barth, M. C., and Wong, J.: Radiative forcing due to sulfate aerosols from simulations with the National Center for Atmospheric Research Community Climate Model, Version 3, J. Geophys. Res.-Atmos., 105, 14411457, 2000.

Koch, D., Jacob, D., Tegen, I., Rind, D., and Chin, M.: Tropospheric sulfur simulation and sulfate direct radiative forcing in the Goddard Institute for Space Studies general circulation model, J. Geophys. Res.-Atmos., 104, 23 799-23 822, 1999.

Koch, D. M., Jacob, D. J., and Graustein, W. C.: Vertical transport of tropospheric aerosols as indicated by $\mathrm{Be}-7$ and $\mathrm{Pb}-210$ in a chemical tracer model, J. Geophys. Res.-Atmos., 101, 18651$18666,1996$.

Kulmala, M., Laaksonen, A., and Pirjola, L.: Parameterizations for 
sulfuric acid/water nucleation rates, J. Geophys. Res.-Atmos., 103, 8301-8307, 1998.

Lin, S. J. and Rood, R. B.: Multidimensional flux-form semiLagrangian transport schemes, Mon. Weather Rev., 124, 20462070, 1996.

Liu, H. G. Y., Jacob, D., Bey, I., and Yantosca, R. M.: Constraints from $210 \mathrm{~Pb}$ and $7 \mathrm{Be}$ on wet deposition and transport in a global three-dimensional chemical tracer model driven by assimilated meteorological fields, J. Geophys. Res.-Atmos., 106, 12 109$12128,2001$.

Lohmann, U., Leaitch, W. R., Barrie, L., Law, K., Yi, Y., Bergmann, D., Bridgeman, C., Chin, M., Christensen, J., Easter, R., Feichter, J., Jeuken, A., Kjellstrom, E., Koch, D., Rasch, P., and Roelofs, G. J.: Vertical distributions of sulfur species simulated by large scale atmospheric models in COSAM: Comparison with observations, Tellus B, 53, 646-672, 2001.

Martin, G. M., Johnson, D. W., and Spice, A.: The measurement and parameterization of effective radius of droplets in warm stratocumulus clouds, J. Atmos. Sci., 51, 1823-1842, 1994.

Monahan, E. C., Spiel, D. E., and Davidson, K. L.: A model of marine aerosol generation via whitecaps and wave disruption, Oceanic Whitecaps, 167-174, 1986.

Pandis, S. N., Wexler, A. S., and Seinfeld, J. H.: Dynamics of Tropospheric Aerosols, J. Phys. Chem.-US, 99, 9646-9659, 1995.

Park, R. J., Jacob, D. J., Field, B. D., Yantosca, R. M., and Chin, M.: Natural and transboundary pollution influences on sulfate-nitrate-ammonium aerosols in the United States: Implications for policy, J. Geophys. Res.-Atmos., 109, D15204, doi:10.1029/2003JD004473, 2004.

Pierce, J. R. and Adams, P. J.: Global evaluation of CCN formation by direct emission of sea salt and growth of ultrafine sea salt, J. Geophys. Res.-Atmos., 111, D06203, doi:10.1029/2005JD006186, 2006.

Pierce, J. R. and Adams, P. J.: Efficiency of cloud condensation nuclei formation from ultrafine particles, Atmos. Chem. Phys., 7, 1367-1379, 2007, http://www.atmos-chem-phys.net/7/1367/2007/.

Raes, F., Bates, T., McGovern, F., and Van Liedekerke, M.: The 2nd Aerosol Characterization Experiment (ACE-2): general overview and main results, Tellus B, 52, 111-125, 2000a.

Raes, F., Van Dingenen, R., Vignati, E., Wilson, J., Putaud, J. P., Seinfeld, J. H., and Adams, P.: Formation and cycling of aerosols in the global troposphere, Atmos. Environ., 34, 4215-4240, $2000 \mathrm{~b}$.

Ramanathan, V., Crutzen, P. J., Lelieveld, J., Mitra, A. P., Althausen, D., Anderson, J., Andreae, M. O., Cantrell, W., Cass, G. R., Chung, C. E., Clarke, A. D., Coakley, J. A., Collins, W. D., Conant, W. C., Dulac, F., Heintzenberg, J., Heymsfield, A. J., Holben, B., Howell, S., Hudson, J., Jayaraman, A., Kiehl, J. T., Krishnamurti, T. N., Lubin, D., McFarquhar, G., Novakov, T., Ogren, J. A., Podgorny, I. A., Prather, K., Priestley, K., Prospero, J. M., Quinn, P. K., Rajeev, K., Rasch, P., Rupert, S., Sadourny, R., Satheesh, S. K., Shaw, G. E., Sheridan, P., and Valero, F. P. J.: Indian Ocean Experiment: An integrated analysis of the climate forcing and effects of the great Indo-Asian haze, J. Geophys. Res.-Atmos., 106, 28 371-28 398, 2001.

Rind, D. and Lerner, J.: Use of on-line tracers as a diagnostic tool in general circulation model development 1 . Horizontal and vertical transport in the troposphere, J. Geophys. Res.-Atmos., 101, 12 667-12 683, 1996.
Roelofs, G. J., Lelieveld, J., and Ganzeveld, L.: Simulation of global sulfate distribution and the influence on effective cloud drop radii with a coupled photochemistry sulfur cycle model, Tellus B, 50, 224-242, 1998.

Roelofs, G. J., Kasibhatla, P., Barrie, L., Bergmann, D., Bridgeman, C., Chin, M., Christensen, J., Easter, R., Feichter, J., Jeuken, A., Kjellstrom, E., Koch, D., Land, C., Lohmann, U., and Rasch, P.: Analysis of regional budgets of sulfur species modeled for the COSAM exercise, Tellus B, 53, 673-694, 2001.

Spracklen, D. V., Pringle, K. J., Carslaw, K. S., Chipperfield, M. P., and Mann, G. W.: A global off-line model of size-resolved aerosol microphysics: II. Identification of key uncertainties, Atmos. Chem. Phys., 5, 3233-3250, 2005a,

http://www.atmos-chem-phys.net/5/3233/2005/.

Spracklen, D. V., Pringle, K. J., Carslaw, K. S., Chipperfield, M. P., and Mann, G. W.: A global off-line model of size-resolved aerosol microphysics: I. Model development and prediction of aerosol properties, Atmos. Chem. Phys., 5, 2227-2252, 2005b, http://www.atmos-chem-phys.net/5/2227/2005/.

Spracklen, D. V., Carslaw, K. S., Kulmala, M., Kerminen, V. M., Mann, G. W., and Sihto, S. L.: The contribution of boundary layer nucleation events to total particle concentrations on regional and global scales, Atmos. Chem. Phys., 6, 5631-5648, 2006, http://www.atmos-chem-phys.net/6/5631/2006/.

Spracklen, D. V., Pringle, K. J., Carslaw, K. S., Mann, G. W., Manktelow, P., and Heintzenberg, J.: Evaluation of a global aerosol microphysics model against size-resolved particle statistics in the marine atmosphere, Atmos. Chem. Phys., 7, 2073-2090, 2007, http://www.atmos-chem-phys.net/7/2073/2007/.

Stevens, B., Feingold, G., Cotton, W. R., and Walko, R. L.: Elements of the microphysical structure of numerically simulated nonprecipitating stratocumulus, J. Atmos. Sci., 53, 980-1006, 1996.

Stier, P., Feichter, J., Kinne, S., Kloster, S., Vignati, E., Wilson, J., Ganzeveld, L., Tegen, I., Werner, M., Balkanski, Y., Schulz, M., Boucher, O., Minikin, A., and Petzold, A.: The aerosol-climate model ECHAM5-HAM, Atmospheric Chemistry and Physics, 5, 1125-1156, 2005a.

Stier, P., Feichter, J., and Kloster, S.: Emission-Induced Nonlinearities in the Global Aerosol System - Results From the ECHAM5HAM Aerosol Climate Model, 2005b.

Stockwell, D. Z. and Chipperfield, M. P.: A tropospheric chemicaltransport model: Development and validation of the model transport schemes, Q. J. Roy. Meteor. Soc., 125, 1747-1783, 1999.

Textor, C., Schulz, M., Guibert, S., Kinne, S., Balkanski, Y., Bauer, S., Berntsen, T., Berglen, T., Boucher, O., Chin, M., Dentener, F., Diehl, T., Easter, R., Feichter, H., Fillmore, D., Ghan, S., Ginoux, P., Gong, S., Kristjansson, J. E., Krol, M., Lauer, A., Lamarque, J. F., Liu, X., Montanaro, V., Myhre, G., Penner, J., Pitari, G., Reddy, S., Seland, O., Stier, P., Takemura, T., and Tie, X.: Analysis and quantification of the diversities of aerosol life cycles within AeroCom, Atmos. Chem. Phys., 6, 1777-1813, 2006, http://www.atmos-chem-phys.net/6/1777/2006/.

Twomey, S.: Pollution and Planetary Albedo, Atmos. Environ., 8, 1251-1256, 1974.

Twomey, S.: Influence of Pollution on Shortwave Albedo of Clouds, Journal of the Atmospheric Sciences, 34, 1149-1152, 1977. 
Tzivion, S., Feingold, G., and Levin, Z.: An Efficient NumericalSolution to the Stochastic Collection Equation, J. Atmos. Sci., 44, 3139-3149, 1987.

Tzivion, S., Feingold, G., and Levin, Z.: The Evolution of Raindrop Spectra. 2. Collisional Collection Breakup and Evaporation in a Rainshaft, J. Atmos. Sci., 46, 3312-3327, 1989.

von Salzen, K., Leighton, H. G., Ariya, P. A., Barrie, L. A., Gong, S. L., Blanchet, J. P., Spacek, L., Lohmann, U., and Kleinman, L. I.: Sensitivity of sulphate aerosol size distributions and $\mathrm{CCN}$ concentrations over North America to $\mathrm{SO}_{\mathrm{x}}$ emissions and $\mathrm{H}_{2} \mathrm{O}_{2}$ concentrations, J. Geophys. Res.-Atmos., 105, 9741-9765, 2000.

Wang, Y. H., Jacob, D. J., and Logan, J. A.: Global simulation of tropospheric $\mathrm{O}_{3}-\mathrm{NO}_{\mathrm{x}}$-hydrocarbon chemistry 1 . Model formulation, J. Geophys. Res.-Atmos., 103, 10 713-10 725, 1998.
Wesely, M. L.: Parameterization of Surface Resistances to Gaseous Dry Deposition in Regional-Scale Numerical-Models, Atmos. Environ., 23, 1293-1304, 1989.

Wexler, A. S., Lurmann, F. W., and Seinfeld, J. H.: Modelling urban and regional aerosols - I. Modeling development, Atmos. Environ., 28, 531-546, 1994.

Wilson, J., Cuvelier, C., and Raes, F.: A modeling study of global mixed aerosol fields, J. Geophys. Res.-Atmos., 106, 34 08134 108, 2001.

Zhang, L. M., Gong, S. L., Padro, J., and Barrie, L.: A sizesegregated particle dry deposition scheme for an atmospheric aerosol module, Atmos. Environ., 35, 549-560, 2001. 